\title{
The Legal Value of Prior Steps to Arbitration in International Law of Foreign Investment: Two (Different?) Approaches, One Outcome
}

\author{
El valor jurídico de los prerrequisitos de arbitraje \\ en el derecho internacional de inversión extranjera: \\ dos aproximaciones (¿distintas?), un mismo resultado
}

Juan Pablo Hugues Arthur*

SumARIO: I. Introduction. II. The Conceptual Framework: Jurisdiction, Admissibility and Seisin. III. Nature and Interpretation of the Prior Steps to Arbitration. IV. Legal Value of the Prior Steps to Arbitration: the Approaches. V. Conclusion. VI. Bibliography.

* Law Degree (Highest Honors) (CIDE). Attorney-Counsel for the Legal Adviser, Ministry of Foreign Affairs, Mexico. I would like to thank the support and advice provided by Mr. Luis Jardón, Mrs. Kate Brown de Vejar, Mrs. Jimena Moreno and Mr. Rafael Llano Oddone.

Artículo recibido el 10 de julio de 2014 Aprobado para publicación el 24 de septiembre de 2014 
ABSTRACT: The present article proposes two different approaches to determine whether the failure to comply with prior steps to arbitration — negotiations or domestic litigation for a period of time - is a matter pertaining to the admissibility of a claim, jurisdiction or seisin of a tribunal. Under the first approach, the non-compliance with the prior steps represent an implicit rejection of the arbitration offer made by the host State and thus their legal value is jurisdictional strictu sensu. Under the second approach, the legal value of the prior steps is that they constitute prerequisite conditions for the seisin of a tribunal. Under either approach, the juridical outcome proposed by this article is that a tribunal may not address the merits of the case submitted.

Key words: jurisdiction of international tribunals, admissibility of claims, seisin of international tribunals, international law of foreign investment, investment arbitration, settlement of international disputes, interpretation of treaties.

RESUMEN: El presente artículo propone dos perspectivas para determinar si el incumplimiento de prerrequisitos de arbitraje — negociaciones o litigio doméstico- es una cuestión de admisibilidad de la demanda, jurisdicción o prevención (seisin) del tribunal. Desde la primera perspectiva, al incumplir con los prerrequisitos de arbitraje, el inversionista rechaza implícitamente la oferta arbitral realizada por el Estado receptor y ergo el valor jurídico de los prerrequisitos es jurisdiccional strictu sensu. Bajo la segunda perspectiva, los prerrequisitos son condiciones de la prevención (seisin) del tribunal. Bajo ambas perspectivas, el resultado jurídico propuesto es que el tribunal no puede resolver el fondo de la controversia.

Palabras clave: jurisdicción de tribunales internacionales, admisibilidad de demandas, prevención de tribunales internacionales, derecho internacional de inversión extranjera, arbitraje de inversión, solución de controversias internacionales, interpretación de tratados.

RÉSUMÉ: Le présent article propose deux approches pour déterminer si la violation des négociations ou litiges nationaux avant l'arbitrage, établies dans une clause arbitral, est une question de la recevabilité d'une réclamation, de la compétence ou la saisine du tribunal. Selon la première approche, la violation en cas représente un rejet implicite de l'offre d'arbitrage faite par l'État hôte et donc leur valeur juridique est de compétence strictu sensu. En vertu de la deuxième approche, les étapes préalables représentent des conditions de saisine du tribunal. Sous les deux approches, le résultat juridique proposé est que le tribunal ne peut aborder le fond de l'affaire soumis.

Mots-clés: juridiction des tribunaux internationaux, recevabilité des réclamations, saisine des tribunaux internationaux, droit international d'investissement étranger, arbitrage d'investissement, règlement de différences internationaux, interprétation de traites internationaux. 


\section{INTRODUCTION}

In recent years, there has been no uniformity pertaining to the legal value of negotiations or domestic litigation for a period of time prior to international arbitration (prior steps to arbitration). This discrepancy derives from the fact that at the time of characterizing these prior steps into legal institutions that determine the faculty of an international adjudicative body to deal with the merits of a case or a claim, such as jurisdiction, admissibility or seisin, tribunals have come to different results. Some have considered them as irrelevant admissibility elements which, in the presence of noncompliance by the claimant, do not prevent the tribunal from awarding a judgment on the merits. Others have established that they are fundamental jurisdictional conditions and, in the presence of non-compliance, have opted to dismiss the case. ${ }^{1}$

This sort of legal discrepancies gains importance since, in one hand, it poses serious problems for International Law of Foreign Investment (ILFI) in particular, and to Public International Law (PIL) in general, as it calls into question the legitimacy of both legal systems. ${ }^{2}$ On the other hand, it can also have serious economic consequences. For instance, one of the

1 For reference to cases which have analyzed the legal nature of the prior steps to arbitration and their legal consequences in case of non-compliance, see footnote 77 below and Abaclat and others v. Argentine Republic (Decision on Jurisdiction and Admissibility) (ICSID Case No ARB/07/5) (4 August 2011) [Abaclat v. Argentina] §§ 585-8; TSA Spectrum de Argentina, SA v. Argentine Republic (Award) (ICSID Case No ARB/05/5) (19 December 2008) [Hereinafter: TSA Spectrum v. Argentina] $\S \S 112-13$; Occidental Petroleum Corporation and Occidental Exploration and Production Company v. Republic of Ecuador (Decision on Jurisdiction) (ICSID Case No ARB/06/11) (9 September 2008) §§ 90-5; Biwater Gauff (Tanzania) Limited v. United Republic of Tanzania (Award) (ICSID Case No ARB/05/22) (24 July 2008) [Hereinafter Biwater Gauff v. Tanzania] §§ 347-8; Consortium Groupement LESI_DIPENTA v. People's Democratic Republic of Algeria (Award) (ICSID Case No ARB/03/8) (10 January 2005) §32(iv); SGS Société Générale de Surveillance SA v. Islamic Republic of Pakistan (Decision on Objections to Jurisdiction) (ICSID Case No ARB/01/13) (6 August 2003) [Hereinafter: SGS v. Pakistan] § 184.

2 Dimsey. M., The Resolution of International Investment Disputes: International Commerce and Arbitration 98, Ingeborg Schwenzer ed., 2008; Brower, C. N. et al., "The Coming Crisis in the Global Adjudication”, 19 Arbitration International 415, 2003; Rivkin, D. W., "Towards a New Paradigm in International Arbitration: The Elder Town Model Revisited" 24 Arbitration International 375, 2008, p. 377; Waibel, M. et al., "The Backlash Against Investment Arbitration: 
most controversial juridical issues at the core of the $B G$ Group v.Argentina saga was whether if a foreign investor fails to meet the prior steps to arbitration established in a Bilateral Investment Treaty (BIT) the international tribunal before which the dispute is submitted has jurisdiction to deal with the merits of the case. ${ }^{3}$ In 17 January 2012, the US Court of Appeals for the District of Columbia Circuit ruled in the negative on this question. ${ }^{4}$ Nonetheless, last March, the Supreme Court of the United States reversed this decision, ${ }^{5}$ but failed to deal with the legal value of prior steps to arbitration and its juridical consequences in particular, ${ }^{6}$ allowing thus in practical terms the

Perceptions and Reality", in Waibel, M. et al. (eds.), The Backlash Against Investment Arbitration: Perceptions and Reality, The Netherlands, Kluwer Law International, p. xxxvii.

3 See Bjorklund, A., Case Comment: Republic of Argentina v BG Group PLC (2012) 27 ICSID Review 1; Folkman, T., Case of the Day: Republic of Argentinva v BG Group PLC, Letters Blogatory, (Available at http://lettersblogatory.com/2012/01/19/argentina-bg-group/. Last visited: 2 September 2014); M. Athanasiou, Argentina v BG Group PLC: The U.S. Court of Appeal's (mistaken?) Decision, Blog Arbitration, January 25, 2012, (Available at http://blogarbitration. com/2012/01/25/argentina-v-bg-group-plc-the-u-s-court-of-appeals-mistakendecision/. Last visited: 2 September 2013); DLA Piper, Republic of Argentina v GB Group: "arbitrability" as a threat to the finality of international arbitration awards (Available at http: / / www.dlapiper.com / republic-of-argentina-v-bg-group-arbitrability-as-a-threat-to-the-finalityofinternational-arbiration-awards /. Last visited: 2 September 2014); J Kalicki y K Yamane, The Unavoidability of Uncertainty: One Lesson from the Recent U.S. Court Ruling in Argentina v BG Group, Kluwer Law Arbitration (Available at http: / / kluwer.practicesource.com/blog/2012/the-unavoidability-ofuncertainty-one-lesson-from-therecent-u-s-court-ruling-in-argentina-v-bg-group/. Last visited: 2 September 2014); C Amirfar y D Rivkin, Who Decides Arbitrability? A Resurgence of the Debate in the United States, Global Arbitration Review News, (Available at http://www.globalarbitrationreview.com/reviews/48/sections/166/ chapters / 1863/. Last visited: 2 September 2014); I Gedwillo, La anulación del laudo de BG Group LLC ${ }_{v}$ Republic of Argentina y sus implicancias para el futuro del abritraje de inversión, Arbitrabje Comercial Internacional, (Available at http://www.arbitrajecomercial.com/BancoConocimiento/L/ la_anulacion_del_laudo_de_bg_group_llc_v_republic_of_argentina/la_anulacion_del_laudo_de_ bg_group_llc_v_republic_of_argentina. Last visited 2 September 2014).

4 Republic of Argentina v. BG Group PLC (District of Columbia) (Court of Appeals) (2012) No. 1:08-cv-00485 [Hereinafter: Argentina v. BG Group].

5 Bg Group PLC Petitioner v. Republic of Argentina, 572 Supreme Court of the United States (2014) (No. 12-138) (4 March 2014).

6 Ebere, S. \& Xheraj, B., "Who Decides Arbitrability Where a Precondition to Arbitration Has Not Been Satisfied?: A Comment on the U.S. Supreme Court's Decision to Hear the Appeal in BG Group v. Argentina”, 31 Journal of International Arbitration 1, 2014; Lavin, C., BITs as Contracts, and Lurking Consent Issues: BG Group v. Republic of Argentina (21 March 2014) (Available at: http://kluwerarbitrationblog.com/blog/2014/03/21/bits-as-contracts-and-lurkingconsent-issues-bg-group-v-republic-of-argentina/. Last visited: 5 April 2014). 
enforcement of a US\$185,969,858 plus GB£2,414,141.107 international arbitration award against Argentina. Although the last two decisions are not international strictu sensu, they shed light on the economic consequences that the international legal debate concerning this work can have to one party of a dispute.

In light of the aforementioned, in the present article, I will argue in favor of the posture that whenever the prior steps to arbitration are not fulfilled, the arbitral tribunal has no jurisdiction over the merits of the dispute. In order to support this position, I will present two approaches that lead to the same juridical outcome: (i) a more "classical approach" in which the prior steps represent an arbitration offer by the host State that the investor rejects, and (ii) a more "innovative approach" in ILFI that considers the prior steps as conditions of seisin the arbitral tribunal.

To develop and prove this, I will divide this article into three main sections. First, I will explain the three different legal institutions in which the prior steps to arbitration might fit: jurisdiction, admissibility and seisin. The meaning of each institution, its relevance, its treatment in international practice and doctrine and, above all, their differences will be explored in the context of PIL and ILFI. In the second section, I will analyze the conceptual and legal value of the prior steps to arbitration to prove their mandatory nature, by elaborating on the legal interpretation of them. Finally, in the third section, after espousing the position that other international tribunals have taken in the subject-matter of this article, I will present the two different approaches from which the legal value of the prior steps could derive, the factual and legal implications of these approaches and how it is that some investors have in practice found an outlet from the legal consequences of non-compliance with them.

Throughout this paper, constant reference will be made to the case law of the International Court of Justice (ICJ) and the Permanent Court of International Justice (PCIJ) for, as extolled by Professor Pellet, "international investment law has its roots in general international law" ${ }^{\text {" }}$ and both "Court[s] [have] a significant influence on investment tribunals", ${ }^{9}$ especial-

7 BG Group PLC v. Argentina (Final Award) (UNICTRAL) (24 December 2007) [Hereinafter: $B G$ Group v. Argentina] § 467(4)(6)(7).

8 Pellet, A., 2013 Lalive Lecture, The Case Law of the ICJ in Investment Arbitration (2013) 22 ICSID Review 2, p. 240.

9 Idem. 
ly in treaty interpretation and the faculty of an international adjudicative body to address the merits of a case. ${ }^{10}$

\author{
II. THE CONCEPTUAL FrameWORK: \\ JURISDICTION, ADMISSIBILITY AND SEISIN
}

To identify the subject of research concerning this work, I will use a clause that I will call "generic." This clause will be useful to give an interpretation and evaluation of the prior steps to arbitration. The clause is as follows:

Any dispute relating to an investment shall be negotiated or submitted to the decision of a competent domestic court of the Host State of the investment. Such disputes shall be submitted to arbitration whenever (i) 6 months have elapsed since the beginning of the negotiations; or (ii) after a period of 18 months starting from the moment in which the dispute was submitted to the competent domestic court of the Host State of the investment and such court has not rendered its final decision, or (iii) whenever the latter has rendered a decision but the dispute remains. ${ }^{11}$

10 See Ibidem, pp. 231, 240.

11 A generic clause was opted instead of a real clause existing in one particular Treaty in virtue of the fact that, in this way, the legal result obtained from the interpretation of this generic clause can be applied to other clauses that, whilst drafted differently, share the same or similar meaning. In virtue of this, key shared sentences and legal objectives shared by several dispute settlement mechanism clauses in different BIT's were taken to draft this clause. See inter alia Agreement Between The Republic Of Hungary And The Republic Of Paraguay For The Encouragement And Reciprocal Protection Of Investments (Signed 11 August 1993, entry into force 1 April 1995), art. 10; Agreement on Encouragement and Reciprocal Protection of Investments between the Kingdom of the Netherlands and the Oriental Republic of Uruguay (Signed 22 September 1988, entry into force 01 August 1991) 2242 UNTS 139, art. 9; Agreement on Encouragement and Reciprocal Protection of Investments between the Kingdom of the Netherlands and Jamaica (Signed 18 April 1991, entry into force 01 August 1992) 2240 UNTS 3, art. 9; Agreement between the Government of the United Kingdom of Great Britain and Northern Ireland and the Government of the Republic of Argentina for the Promotion and Protection of Investments (Signed 11 December 1990, entry into force 19 February 1993) UKTS 41 (1993), Cm 2278, art. X; Agreement between the Government of the Republic of Korea and the Government of the Republic of Argentina on the Promotion and Protection of Investments (Signed 17 May 1994, entry into force 24 September 1996) 2111 UNTS 3, UNTS Reg No 36695, art. 8. 
The former clause is jurisdictional: it relates to the power of an international adjudicative body to settle a dispute. In international litigation the term jurisdiction latu sensu has encompassed other concepts that are different in their species, ${ }^{12}$ but all refer in general to the capacity of a court or tribunal to address the merits of a case and settle a dispute. In the present article, I will exclusively develop the concepts of jurisdiction strictu sensu — which comprises the parties' consent exclusively_ admissibility and seisin. This choice is not arbitrary, since, as will be seen below, both case law and doctrine have characterized the generic clause as one of these three institutions.

\section{Jurisdiction, Admissibility and Seisin in PIL}

\section{A. Jurisdiction}

In PIL, the absolute and exclusive basis for the jurisdiction of international courts and tribunals strictu sensu is consent. ${ }^{13}$ Through this consent, the State involved in an international dispute forfeits part of its sovereignty to be bound by decisions of an international adjudicative body on its substantial rights and obligations. ${ }^{14}$

12 The term jurisdiction has been confused with (i) the power of the tribunal to decide on its own jurisdiction (compétence de la compétence or kompetenz-kompetenz); (ii) the legal constitution of the organ; (iii) the existence of fundamental deficiencies of the dispute submitted to the tribunal in light of its constituent instrument and in terms of the parties and the subjectmatter of the dispute and (iv) the existence of deficiencies inherent to the claim (les conditions de recevabilité or admissibility of a claim). See C F Amerasinghe, Jurisdiction of International Tribunals, The HagueKluwer Law International, 2003 [Amerasinghe, Jurisdiction of International Tribunals] p. 65.

13 Statute of the International Court of Justice (Adopted 25 June 1945, entry into force 24 October 1945) 1 UNTS 993, art. 36; Case Concerning Armed Activities on the Territory of the Congo (Democratic Republic of the Congo v. Rwanda) (New Application: 2002) (Jurisdiction and Admissibility) [2006] ICJ Rep 6 [Hereinafter: Armed Activities on the Territory of the Congo] § 65; Application for Revision and Interpretation of the Judgment of 24 February 1982 in the Case concerning the Continental Shelf (Tunisia/Libyan Arab Jamahiriya) [1982] Judgment, ICJ Rep 192 § 43; Dugan, C. F. et al., Investor-State Arbitration (OUP, 2008), p. 219; Pellet, A., "The Anatomy of Courts and Tribunals", 3 The Law \& Practice of International Courts and Tribunals, 2008.

14 Garanti Koza LLP v.Turkmenistan (Dissenting Opinion by Laurance Boisson de Chazournes) (ICSID Case No. ARB/11/20) (3 July 2013) § 30; Amco v. Indonesia (Decision on Jurisdiction) (1 ICSID Reports 393) (25 September 1983) [Hereinafter: Amco v. Indonesia] p. 397. 
This same consent determines the overall spectrum over which the judicial power and jurisdiction of the court in question rests. ${ }^{15}$ While consent is generally considered the attribution of jurisdiction (l'attribution de jurisdiction), its content comprises l'étendue de jurisdiction. ${ }^{16}$ In particular, this étendue determines the jurisdiction ratione materiae, ratione personae, ratione temporis, ratione loci and ratione voluntatis. Grosso modo, the jurisdiction ratione materie constitutes the specific subject-matter that may settled by the court or tribunal; ${ }^{17}$ the ratione personae comprises the subjects over which the same adjudicative body may exercise jurisdiction $;{ }^{18}$ the ratione temporis determines the time interval during which the court or tribunal may exercise its jurisdiction; ${ }^{19}$ the ratione loci determines the territory over which the court or tribunal has jurisdiction, ${ }^{20}$ and the ratione voluntatis ${ }^{21}$ concerns mutatis mutandis the terms and conditions necessary for the consent given by the parties to be valid as a whole. ${ }^{22}$

15 Douglas. Z., The International Law of Investment Claims, CUP, 2009 [Hereinafter: Douglas, The International Law of Investment Claims], pp. 145, 186-187.

16 See Ibidem. p. 142: “To avoid negotiating the terminological quagmire as a preliminary step in this discussion, three concepts will be introduced and distinguished without using the common terms of art. Instead, the relevant French terms are identified insofar as they are less corrupted by bad practice than their English equivalents".

17 Ibidem. p. 8; See for instance Case Concerning the Payment of Various Serbian Loans in France [1929] Series A No 20 PCIJ, p. 4.

18 Douglas, The International Law of Investment Claims, n. 16, p. 144.

19 See for instance Case Concerning Application of the Convention on the Prevention and Punishment of the Crime of Genocide (Bosnia and Herzegovina v. Yugoslavia) [1996] (Preliminary Objections Judgment) ICJ Rep 595, p. 595 § 34.

20 The discussions on ratione loci jurisdiction have gained much more weight at the European Court of Human Rights. See Amerasinghe, C. F., Jurisdiction of Specific International Tribunals, Leiden-Boston, Martinus Nijhoff, 2009, p. 343.

21 At footnote 26 of his article 'Ménage à trois': Jurisdiction, admissibility and competence in investment treaty arbitration (2013) ICSID Review, Veijo Heiskanen addresses that the existence of a distinction of jurisdiction ratione voluntatis turns redundant since the granting of jurisdiction by the State represents already and per se its will to be bound by the decision of the tribunal. However, for the purposes of this work, it is quite important to draw the precise distinction between jurisdiction ratione voluntatis and the other "sub-divisions" on the scope of the jurisdictional consent of a State.

22 In other words, the jurisdiction ratione voluntatis comprises such conditions that, once met, makes possible to analyze whether jurisdiction ratione materiae, ratione personae, ratione temporis and ratione loci arises as well. For reference to cases where the jurisdiction ratione voluntatis has been analyzed, see Joseph Charles Lemire v. Ukraine (Decision on Jurisdiction and Liability) 
Therefore, having a legal instrument that contains the consent to the jurisdiction of an international tribunal does not suffice for it to address the merits of a dispute. It is mandatory for the tribunal to take into account each and every element of this consent to determine the material, personal, temporal, territorial and voluntary spectrum upon which its jurisdiction rests.

However, it is not merely the consent of the parties that allows a dispute to be dealt with on its merits by an international court or tribunal. Mutatis mutandis, situations may arise in which, notwithstanding the parties have consented to the jurisdiction, the lack of procedural requirements and legal adequacy of a claim prevent it from being resolved on its merits. ${ }^{23} \mathrm{In}$ these situations, we are dealing with the admissibility of claims (les conditions de recevabilité). ${ }^{24}$

\section{B. Admissibility}

This concept has been distinguished from jurisdiction strictu sensu ${ }^{25}$ by the ICJ ${ }^{26}$ In PIL, the inadmissibility of a claim arises whenever inter alia (i) the-

(ICSID Case NO. ARB/06/18) § 45; Phoenix Action v. The Czech Republic (Award) (ICSID Case No. ARB/06/5) (15 April 2009) §54; Garanti Koza LLP v. Turkmenistan (Decision on the objection to jurisdiction for lack of consent) (ICSID Case No. ARB/11/20) (3 July 2013) § 29; CEMEX Caracas Investments B.V. and CEMEX Caracas II Investments B.V. v. Bolivarian Republic of Venezuela (Decision of Jurisdiction) (ICSID Case No. ARB/08/15) (30 December 2010) §58; Boddicker, J., "Whose Dictionary Controls?: Recent Challenges to the Term "Investment" in ICSID Arbitration”, 25 AUILR 5, 2010, p. 1043.

23 Crawford, J., Brownlie's Principles of International Law $\left(8^{\text {th }}\right.$ ed, OUP, 2012) [Hereinafter: Crawford, Brownlie's Principles of International Law] p. 693.

24 Amerasinghe, Jurisdiction of International Tribunals (n.13) p. 241.

25 Interhandel case (Switzerland v. United States of America) [1959] (Preliminary Objections) ICJ Rep 6 [Hereinafter: Interhandel Case] p. 26; Nottebohm (Liechtenstein v. Guatemala) (Second Phase) [1954] ICJ Rep 4, p. 16. For instance, the European Court of Human Rights has always treated every preliminary objection as a matter of admissibility, even when they are jurisdictional, for instance. See Van Dijk, F Van Hoof, A Van Rijn and L Zwaak, Theory and Practice of the European Convention on Human Rights (Hart Publishing, Oxford, 2006).

26 The most controversial cases regarding the distinction between jurisdiction and admissibility were South West Africa Cases (Ethiopia v. South Africa; Liberia v. South Africa) [1962] (Preliminary Objections) ICJ Rep, p. 319; South-West Africa Cases (Second Phase) [1966] ICJ Rep, p. 6. In these cases, the Court asserted its jurisdiction over the dispute. Nonetheless, in a further phase, it found that the claims where inadmissible and thus refrain itself from dealing with the merits of the dispute. 
re is no legal interest in the dispute by the claimant; ${ }^{27}$ (ii) the claim is new with respect to the dispute in question; ${ }^{28}$ (iii) local remedies have not been exhausted; $;^{29}$ (iv) the dispute has been settled; ${ }^{30}$ (v) the claim does not refer to the jurisdictional instrument addressed; ${ }^{31}$ (vi) a third interested party must be heard, ${ }^{32}$ or (vii) the dispute is pending before another adjudicative organ (lis pendens). ${ }^{33}$ Consequently, the admissibility of a claim refers to its legal suitability to be dealt with by a court on its merits and not to the consent of the parties to the dispute. ${ }^{34}$

Albeit distinguishing jurisdiction and admissibility may appear irrelevant, ${ }^{35}$ in the words of Jan Paulsson: "it is vital to understand the crucial distinction between the two concepts. [Although] they are as different as night and day... there is a twilight zone [between them]... [but o]nly a fool would argue that the existence of a twilight zone is proof that day and night do not exist". ${ }^{36}$ However, even with precise definitions of jurisdiction and admissibility, the boundary between the two concepts is blurry. ${ }^{37}$ Doctrine and case law have outlined objective parameters that shed light on when we face jurisdictional or admissibility preliminary objections. In general, an accurate approach is as follows: if the objection concerns the power or faculty of the court or tribunal to deal with the case as a whole, the objection is jurisdictional; if the objection concerns the suitability of a particular claim to be dealt on its merits at a relevant procedural time, the objection regards the admissibility of a the claim. ${ }^{38}$

27 Idem.

28 Certain Phosphate Lands in Nauru (Nauru v. Australia), [1992] ICJ Rep, Pp. 265-267.

29 Interhandel Case, n. 26, p. 24.

30 Case concerning the territorial and maritime dispute (Nicaragua v. Colombia) (Preliminary Objections) [2007] ICJ Rep 832, pp. 872-875 §§ 133-140.

31 Armed Activities on the Territory of the Congo (n.14) pp. 6, 38-41.

32 East Timor Case (Portugal v. Australia) ICJ Rep 1995, p. 90; Case of the monetary gold removed from Rome in 1943 [1954] (Preliminary Question) ICJ Rep 1954, p. 19.

33 MOX Plant Case (Ireland v United Kingdom) (Order No 3) 2003) (PCA) (24 June 2003).

34 Paulsson, J., 'Jurisdiction and admissibility' in G Aksen \& R Briner (eds), Global Reflections on International Law, Commerce and Dispute Resolution, Liber Amicorum in honour of Robert Briner (ICC Publishing, 2005) [Hereinafter: Paulsson, Jurisdiction and admissibility].

35 Idem.

36 Ibidem, p. 603.

37 Ibidem, p. 602.

38 Ibidem, p. 601; Crawford, Brownlie’s Principles of International Law (n.24) p. 693; Douglas, 


\section{Seisin}

Finally, in terms of the powers of an international tribunal to deal with the merits of a case, seisin is yet another fundamental concept. ${ }^{39}$ However, its study has not been as comprehensive as those regarding jurisdiction and admissibility. Its formal treatment, at least in the ICJ, began in $1995 .{ }^{40} \mathrm{In}$ general terms, seisin comprises the formal steps ${ }^{41}$ that represent the manner through which a claimant initiates a proceeding before an international court or tribunal and notifies it (broadly speaking) of the claim or dispute that it intends to litigate. ${ }^{42}$ The validity or invalidity of seisin is usually determined by certain conditions set forth in the constituent instrument of the specific court or tribunal before which the case is submitted, but can also be found in the instrument containing the consent on the jurisdiction of said court or tribunal. ${ }^{43}$ The review and analysis of the validity of seisin precedes the examination of the court or tribunal's jurisdiction and the admissibility of the claims submitted. ${ }^{44}$ It has therefore been argued that only as a result of a valid seisin, compétence de la compétence arises..$^{45}$

The International Law of Investment Claims (n.16) p. 147; ICS Inspection and Control Services Limited v. The Argentine Republic (Award on Jurisdiction) (PCA Case No. 2010-9) (10 February 2012) [Hereinafter: ICS v.Argentina] § 258; Armed Activities on the Territory of the Congo (n.14) p. $6 \S 88$.

39 Weil, P., 'Compétence et saisine: un nouvel aspect du principe de la juridiction consensuelle' in J Makarczyk (ed.), Theory of International Law at the Threshold of the Twenty First Century (Brill Academic Publishers, The Netherlands, 1996) [Hereinafter: Weil, Compétence et saisine: un nouvel aspect du principe de la juridiction consensuelle] p. 833.

40 Thirlway, H., The Law and Procedure of the International Court of Justice 1960-1989 (Parts Nine and Ten) (2001) 1 British Yearbook of International Law 2011 [Hereinafter: Thirlway, H., The Law and Procedure of the International Court of Justice], p. 38.

${ }_{41}$ Rosenne, S., The Law and Practice of the International Court of Justice, 4th edn., vol II, Martinus Nijhoff, 2006, p. 561.

42 Jouannet, E., "Le saisine dans le droit international ou la simplicité dans la diversité", in Ruiz Fabri, H. \& Sorel, J. M. (ed.), La saisine des juridictions internationales, Paris, Pedone, Coll. Contentieux International, 2006, pp. 307-317 [Hereinafter: Jouannet, La saisine dans le droit international ou la simplicité dans la diversité].

43 Idem. For instance, the Statute of the International Court of Justice or its Rules of Procedure. In fact, Professor Jouannet establishes: dis-moi quelle juridiction tu es, je te dirai quelle saisine tu seras.

44 Idem; Amerasinghe, Jurisdiction of International, n. 13, p. 67.

45 Abi-Saab, G., Les exceptions préliminaires dans la procédure de la Cour internationale de Justice, Paris, A. Pedone, 1967, p. 14. 
An invalid seisin is rectifiable, so its invalidity does not prejudice the jurisdictional consent of the parties. ${ }^{46}$ Yet this same invalidity can be translated to a lack of jurisdiction of the adjudicative body. Thus, even if certain authors have considered seisin as a matter of admissibility, ${ }^{47}$ the ICJ, in the Qatar Bahrain case (Jurisdiction and Admissibility), like other scholars ${ }^{48}$ stated:

... It is true that, as an act instituting proceedings, seisin is a procedural step independent of the basis of jurisdiction invoked and, as such, is governed by the Statute and the Rules of Court. However, the Court is unable to entertain a case so long as the relevant basis of jurisdiction has not been supplemented by the necessary act of seisin: from this point of view, the question whether the Court was validly seised appears to be a question of jurisdiction ${ }^{49}$ (Emphasis added).

In fact, in its most recent case law, the ICJ has declined to exercise jurisdiction over the merits of a case by virtue of the non-compliance with the conditions of seisin and its consequent invalidity thereof, notwithstanding the existence of jurisdictional consent and possible admissibility of the claims. ${ }^{50}$

\section{Jurisdiction, Admissibility and Seisin in ILFI}

An international tribunal determines its jurisdiction latu sensu based upon the consent of the parties and its constituent instrument prima facie. ${ }^{51}$

46 Idem.

47 Jouannet, La saisine dans le droit international ou la simplicité dans la diversité, n. 43.

48 Wyler, E., "La détermination par la Cour de sa propre compétence”, in Apostolidis, C (ed.), Les arrêts de la Cour internationale de Justice, Dijon, Etudes universitaires de Dijon, 2005, p. 26.

49 Case concerning Maritime Delimitations and Territorial Questions between Qatar and Bahrain (Jurisdiction and Admissibility) [1995] ICJ Rep 6 [Hereinafter: Qatar and Bahrain case] p. 23.

50 Armed Activities on the Territory of the Congo (n.14) $\S \S 87-88$; Case concerning Application of the International Convention on the Elimination of All Forms of Racial Discrimination (Georgia v. Russian Federation Case) [2011] (Decision on Preliminary Objections) ICJ Rep [Hereinafter: Georgia v. Russian Federation Case] $§ \S 133-134$. Likewise, see the analysis of the conditions of seisin of the ICJ in Questions Relating to the Obligation to Prosecute or Extradite (Belgium v Senegal) [2012] ICJ Rep $144 \$ \$ 56-63$.

51 Brown, C., A Common Law of International Adjudication, OUP, 2007, p. 5; Gray, C., Judicial Remedies in International Law, OUP, 1987, pp. 122-127. 
However, an adjudicative body may seek recourse to general principles of PIL pertaining to the jurisdiction and seisin of tribunals or admissibility of claims whilst dealing with preliminary objections in these regards. ${ }^{52}$ Nothing prevents ILFI arbitration tribunals from taking the same path when dealing with similar objections, since they are international bodies as well. ${ }^{53}$ These tribunals are international since they deal with international disputes; i.e. disputes between a State and an alien ${ }^{54}$ and, most importantly, since their constituent instruments are international treaties..$^{55}$ But what changes and what remains of the initial concepts of this section within ILFI?

\section{A. Similarities between PIL and ILFI concerning Jurisdiction, Admissibility and Seisin}

Pertaining to international investment disputes settlement, the PIL consent-equals-jurisdiction equivalence is reproduced in ILFI. ${ }^{56}$

Regarding the admissibility of claims, certain tribunals have argued that such a concept does not apply in investment arbitration. ${ }^{57}$ Nonetheless,

52 Kolb, R., "General Principles of Procedural Law”, in Zimmermann, A. et al. (eds.), The Statute of the International Court of Justice. A Commentary, OUP, 2006, pp. 793, 794; Douglas, The International Law of Investment Claims, n. 16, p. 77.

53 Amerasinghe, Jurisdiction of International Tribunals, n. 13, p. 1

54 Ibidem. p. 6. For instance, the arbitral tribunals in Arabia v. Aramco (1958), 27 ILR p. 117 and LIAMCO v. Libyan Arab Republic (1977), 62 ILR p. 141.

55 Amerasinghe, Jurisdiction of International Tribunals, n.13, p. 8.

56 Convention on the Settlement of Investment Disputes between States and Nationals of Other States (Adopted 18 March 1965, entry into force 14 October 1966) 17 U.S.T. 1270; T.I.A.S. No.6090, 475 U.N.T.S. 195 [Hereinafter: ICSID Convention] Art. 25; Schreurer, C., 'Consent to Arbitration' in Dispute Settlement: International Centre for Settlement of Investment Disputes, (2003) UNCTAD [Hereinafter: Schreuer, Consent to arbitration]; ICS v. Argentina (n.39) $\S 255$; W M Tupman, Case Studies in the Jurisdiction of the International Centre for Settlement of Investment Disputes (1986) 35 ICLQ 813, p. 813; Report of the Executive Directors on the Convention on the Settlement of Investment Disputes between States and Nationals of Other States (18 March 1965) (Available at https://icsid.worldbank.org/ICSID/StaticFiles/basicdoc/partB-section05. htm\#02. Last visited: 10 may 2014) § 23; W Rank, R Hornick y P Friedland, ICSID Emerging Jurisprudene:The Scope of ICSID's Jurisdiction, (1986-1987) 19 NYJIntL\&Pol 33 [Hereinafter:W. Rank et al., ICSID Emerging Jurisprudence:The Scope of ICSID’s Jurisdiction] p. 52.

57 Ambiente Ufficio SpA and others $v$ Argentina (Decision on Jurisdiction and Admissibility) (ICSID Case No ARB/08/9) (8 February 2013) § 572; Methanex Corporation v. United States of America (Partial Award) (UNCITRAL) (7 August 2002) §§ 123-124. See also Salini Costruttori 
both doctrine and case law currently recognize the concept of admissibility or recevabilité in foreign investment disputes. ${ }^{58}$ In fact, its distinction with jurisdictional issues gains further relevance and weight in ILFI. A tribunal's decision on the admissibility of a claim cannot be overruled neither by a State party's domestic court nor an ad hoc committee of the International Centre for Settlement of Investment Disputes (ICSID), since that decision was made under the jurisdictional power vested to the tribunal. ${ }^{59}$ Conversely, if a tribunal finds jurisdiction (l'attribution of jurisdiction) to adjudicate the merits of a case based on an erroneous legal analysis of the jurisdictional clause, then its decision can be reversed since, in fact, it may have not been vested with such authority. ${ }^{60}$

Finally, although there have been certain ILFI cases concerning questions of seisin in a strict sense, no tribunal has dismissed a case based on the invalidity of seisin or given a serious treatment of this specific concept. ${ }^{61}$ How-

S.p.A. and Italstrade S.p.A. v. Hashemite Kingdom of Jordan (Decision on Jurisdiction) (ICSID Case No. ARB/02 /13) (29 November 2004); Enron Corporation and Ponderosa Assets L.P. v. The Argentine Republic (Decission on Jurisdiction) (ICSID Case No. ARB/01/3) § 33; Bayindir Insaat Turizm TicaretVe Sanayi A.S. v. Islamic Republic of Pakistan (Decision on Jurisdiction) (ICSID Case No. ARB/03/29) [Hereinafter: Bayindir v. Pakistan] § 87; Pan American Energy LLC and BP Argentina Exploration Company v. Argentine Republic (Decision on Preliminary Objections) (ICSID Case No ARB/03/13) (27 July 2006) § 54.

58 Zeiler, G., 'Jurisdiction, Compétence and Admissibility of Claims in ICSID arbitration proceedings', in Binder, C. et al. (eds.), International Investment Law for the $21^{\text {st }}$ Century, Essays in Honour of Christoph Schreuer (OUP, 2009); Daimler Financial Services AG v. The Republic of Argentina (Award) (ICSID Case No. ARB/05/1) (2012) [Hereinafter: Daimler v. Argentina]; Antoine Goetz et consorts c. République du Burundi (Sentence) (Affaire CIRDI ARB/95/3) (10 Février 1999) [Hereinafter: Antoine Goetz c Burundi]; Waste Manangement Inc. v. United Mexican States (Dissenting Opinion Keith Highet) (Case No. ARB(AF)/00/3) (30 April 2004) § 56-58.

59 Paulsson, Jurisdiction and admissibility (n.35) p. 601; Douglas, The International Law of Investment Claims (n.16) p. 146. See for further reference: English Arbitration Act 1996, art. 67; French Code of Civil Procedure, Art. 1502; United States Federal Arbitration Act, art. 10 (a) (4); UNCITRAL Model Law on International Commercial Arbitration, art. 34 (2) (a) (iii); Swiss Private International Law Statute, arts. 190 (2) (b), 190 (2) (c).

$60 \mathrm{Ibidem}$. See Argentina v. BG Group (n.5) The Court reverted the enforcement of the arbitral award due to an excess of powers by the international tribunal. ICSID Convention (n.57) art. 52(b). See in this same regard Soufraki v. United Arab Emirates (Decision on the Application for Annulment) (ICSID Case No ARB/02/7) (5 June 2007) § 42.

${ }^{61}$ For instance, at footnote 358 of Daimler v. Argentina, the tribunal cited a decision of the ICJ concerning the same jurisdictional matter. Although the tribunal phrased the Court's decision acknowledging that the invalidity of the seisin was the ratio decidendis for the Court 
ever, nothing prevents a counsel from arguing that the seisin was invalid in foreign investment arbitration or a tribunal to decline its jurisdiction on the merits of a case for this matter as well. ${ }^{62}$

\section{B. ILFI Differences and Particularities concerning Jurisdiction, Admissibility and Seisin}

With regard to ILFI, there are special issues within the concepts explored that are worth explaining. First, if the dispute is submitted to an ICSID tribunal, the compromissory or arbitral clause must be in writing. ${ }^{63}$ Moreover, in terms of l'étendue of jurisdiction, the jurisdiction ratione materiae of the tribunal concerns (i) legal ${ }^{64}$ and (ii) investment disputes. ${ }^{65}$ In terms

to decline its jurisdiction over the case, the tribunal did not take the same legal approach. Daimler v. Argentina (n. 59).

62 Amerasinghe, Jurisdiction of International Tribunals (n.13) p. 68.

63 ICSID Convention (n. 57) art. 25; W Rank et al, ICSID Emerging Jurisprudence: The Scope of ICSID's Jurisdiction (n. 57) p. 50.

${ }^{64}$ For instance, in the ICSID Convention there is no definition of the term "legal dispute." Not even a clear definition on the jurisdictional instrument would ensure that an international tribunal renders the dispute submitted before it as legal. However, the definition provided by the PCIJ in the Mavromatis Palestine Concessions case is generally looked up. In that case, the Court established that a "dispute is a disagreement on a point of law or fact, a conflict of legal views or of interests between two persons". Mavromatis Palestine Concessions (Greece v. U.K.) [1924] Series A No 2, PCIJ Rep [Hereinafter: Mavromatis Palestine Concessions] p. 11.

65 ICSID Convention (n.57) art. 25. The ICSID Convention does not provide any definition of the term "investment." This concept created vast discussions in both the doctrine and case law. Nevertheless, almost every BIT establishes what should be understood as an investment. See for instance Article 1(2) of the BIT between Turkey and Pakistan; P Szasz, The Investment Disputes Convention: Opportunities and Pitfalls (how to submit to ICSID), (1970-1971) 5 JLED 23 [Hereinafter: Szasz, The Investment Disputes Convention: Opportunities and (how to submit to ICSID)] p. 35; Article 30 of the Draft Convention of September 1I, 1964 reproduced as Doc. 43 in 11 The History 610. Furthermore, in any event the test applied in the Salini case is a common reference to determine whether certain property right of a claimant constitutes an investment. The test, as phrased by the Jan de Nul tribunal, comprises the following elements: (i) a contribution, (ii) a certain duration over which the project is implemented, (iii) a sharing of operational risks, and (iv) a contribution to the host State's development, being understood that these elements may be closely interrelated, should be examined in their totality, and will normally depend on the circumstances of each case. See Salini Costruttori S.p.A. and Italstrade S.p.A. v. Kingdom of Morocco (Decision on Jurisdiction) (ICSID Case No. ARB/00/4) (23 July 2001); Joy Mining Machinery Limited v. The Arab Republic of Egypt (Decision 
of jurisdiction ratione personae, the parties to the dispute must necessarily be (i) a State (party to the ICSID Convention, if recourse is made to such fora $)^{66}$ and (ii) an investor of another State - either an individual or an enterprise ${ }^{67}$ Pertaining to its jurisdiction ratione temporis, the instrument containing the parties' consent must be valid and in force at the time the tribunal is constituted.$^{68}$ In terms of jurisdiction ratione loci, BIT's are generally applicable throughout the territory where a State enjoys full sovereignty, and sovereign or jurisdictional rights. ${ }^{69}$ Finally, as to the jurisdiction ratione

on Jurisdiction) (ICSID Case No. ARB/03/11) (6 August 2004) §53; Consortium Groupement L.E.S.I. - DIPENTA v. République Algérienne Démocratique et Populaire (Award) (27 December 2004) § 13(iv); Jan de Nul N.V. Dredging International N.V.v. Arab Republic of Egypt (Decision on Jurisdiction) (ICSID Case No. ARB/04/13) § 91.

66 Non State parties to the Convention may as well consent to ICSID arbitration. Such consent would entry into force 30 days after the signature and ratification of the Convention. If there is no signature or ratification, the arbitration may be administrated under the ICSID Additional Facilities Rules. Nonetheless, in this case "(i) no official of the Centre is required to accept the function of appointing arbitrators or conciliators as an authority of last resort in connection with such a proceeding [...] [(ii)] the administrative facilities of the Centre cannot be used to assist in the settlement of the dispute, [and (iii)] the arbitral awards of an ad hoc tribunal are neither binding nor enforceable under the provisions of the Convention”. Likewise, constituent subdivisions and agencies of a State party to the Convention can be respondents in ICSID arbitrations. Constituent subdivisions and agencies comprise federal entities, municipalities and even juridical persons under the effective control of the State. See C F Amerasinghe, Jurisdiction Ratione Personae under the Convention on the Settlement of Investment Disputes between States and nationals of other States (1974-1975) 47 British Yearbook of International Law 227 [Hereinafter: Amerasinghe, Jurisdiction Ratione Personae under the Convention on the Settlement of Investment Disputes between States and nationals of other States] pp. 230-232.

67 In the Barcelona Traction case, the ICJ established that the nationality of an investor is determined by its siège social. However, it must be stressed out that this was a statement made in the context of diplomatic protection. Case concerning the Barcelona Traction Light and Power Company Limited (Belgium v. Spain) (Second Phase) (Judgment) [1970] ICJ Rep 4, p. 48. Therefore, pertaining to investment disputes, the nationality of the investors has been a vastly debated issue. There are several features to take into account whilst determining the nationality of an investor, such as (i) who has the ultimate control of the investment; (ii) how to address the double nationality of an investor; (iii) what happens in the case of a State's dissolution, etc. See Amerasinghe, Jurisdiction Ratione Personae under the Convention on the Settlement of Investment Disputes between States and nationals of other States (n.67) p. 463.

68 Szasz, The Investment Disputes Convention: Opportunities and Pitfalls (how to submit to ICSID) (n.66) p. 27; Schreuer, Consent to arbitration (n.57) pp. 25-29.

69 Canada 2004 Bilateral Investment Treaty (Available at http://italaw.com/documents/Canadian2004-FIPA-model-en.pdf. Last visited in 2 May 2014), art.1; France 2006 Model Bilateral Investment Treaty (Available at: http://italaw.com/documents/ModelTreatyFrance2006.pdf. Last 
voluntatis, the specific way in which the consent of the parties is drafted is essential for the valid constitution of the arbitration. ${ }^{70}$ States may offer to arbitrate an investment dispute under certain conditions and thus design and regulate the jurisdiction of the court to their will. ${ }^{71}$ Depending on the specific terms of the treaty, the investor must comply with the arbitration offer according to its terms so that both parties' consent matches. This results in an arbitration agreement and hence the possibility to arbitrate the dispute becomes real. ${ }^{72}$ For instance, States may establish prior steps to $\operatorname{arbitration}^{73}$ such as negotiating the dispute for a period of time, or submitting it to domestic courts for a specific period before the establishment of an arbitral tribunal. ${ }^{74}$

As previously stated, some authors and international tribunals have asserted that prior steps to arbitration are mere procedural elements of admissibility of a claim that have nothing to do with a tribunal's jurisdiction strictu sensu ${ }^{75}$ while others have argued that they constitute a cornerstone jurisdictional requirement. ${ }^{76}$

visited in 2 May 2014), art. 1.5; India 2003 Model Bilateral Investment Treaty (Available at: http: / /www.italaw.com/sites/default/files/archive/ita1026.pdf. Last visited in 2 May 2014), art. 1(ii)f).

70 Szasz, P., The Investment Disputes Convention: Opportunities and Pitfalls (how to submit to ICSID), n. 66, p. 27.

71 Ibidem, p. 28.

72 Wintershall Aktiengesellschaft v. Argentine Republic (Award) (ICSID Case No. ARB/04/14) (2008) [Hereinafter: Wintershall v. Argentina] § 119-122.

73 Schreuer, C., The ICSID Convention, A Commentary (A Commentary on the Convention on the Settlement of Investment Disputes between States and National of Other States), CUP, 2001, p. 234.

74 Asian-African Legal Consultative Committee Model BIT, art. 10(ii), UNCTAD Compendium (vol. III, 1996), p. 122; Chile Model BIT, Art. 8 (1) UNCTAD Compendium (vol. III, 1996), p. 147; China Model BIT, art. 9 (1) UNCTAD Compendium (vol. III, 1996), p. 155; France Model BIT, art. 8 UNCTAD Compendium (vol. III, 1996), p. 163; Tanzania National Investment (Promotion and Protection) art. 1990, sec. 29(1) (Planning Commission P.O. BOX 9242 DAR ES SALAAM, entry into force October 1996).

75 BG Group v. Argentina (n. 8); Schreuer, C., Travelling the BIT route: OfWaiting Periods, Umbrella Clauses and Forks in the Road (2004) 5 JWIT 2 [Hereinafter: Schreuer, C., Of Waiting Periods]; Abaclat v. Argentina, n. 2.

76 ICS v. Argentina (n.39); Abaclat and others v. Argentine Republic (Dissenting Opinion of Professor Georges Abi-Saab) (ICSID Case No. ARB/07/5) (28 October 2011) [Hereinafter: Dissenting Opinion of Professor Georges Abi-Saab]; Daimler v. Argentina (n.59); Kiliç Inş̧aat Ĭthalat Ihracat Sanayi Ve Ticaret Anonim Sirketi v. Turkmenistan (Award) (ICSID Case No. ARB/10/1) (2 
III. NATURE AND INTERPRETATION OF THE PRIOR STEPS TO ARBITRATION

The present section presents a conceptual distinction between the prior steps to arbitration and other similar PIL concepts, and a legal interpretation of the prior steps by utilizing the generic clause, to shed light on its juridical meaning and scope, as many courts and tribunals have done. ${ }^{77}$

\section{Conceptual Nature of the Prior Steps to Arbitration}

\section{A. Bona fide Negotiations}

Previous negotiations, as prior steps to arbitration, have been "cooling off periods" or bona fide negotiations. ${ }^{78}$ However, this analogy is not always adequate. "Cooling off" periods denote a passive attitude of the parties to the dispute. However, as Professor Christoph Schreuer argues, the prior steps to arbitration analyzed here demand active conduct by the claimant: to actually negotiate the dispute. ${ }^{79}$

In addition, bona fide negotiations prior to international litigation already exist as a possibility and ideal in PIL. ${ }^{80}$ Moreover, as a general obligation with no specific requirements for time nor results, the ICJ has consistently determined that neither the interruption of negotiations by the institution of proceedings before the Court, nor the failure to reach a solution of the dispute via negotiations, renders the Court incompetent to deal with the dispute. ${ }^{81}$ Nonetheless, the prior steps established in the

July 2013) [Hereinafter: Kiliç v. Turkmenistan]; C F Amerasinghe, Submission to the Jurisdiction of the International Centre for Settlement of Investment Disputes (1973-1974) 5 JMarL\&Com 211, p. 218.

77 BG Group v. Argentina (n. 8); Murphy Exploration and Production Company International v. The Republic of Ecuador (Award on Jurisdiction) (ICSID Case No. ARB/08/4) (2010) [Hereinafter: Murphy v. Ecuador]; Wintershall v. Argentina (n.73).

78 Schreuer, C., Calvo's Grandchildren: The Return of Local Remedies in Investment Arbitration (2004) 4 The Law and Practice of International Courts and Tribunals [Hereinafter: C Schreuer, Calvo's Grandchildren].

79 Schreuer, C., OfWaiting Periods (n. 76) pp. 238-239.

80 Charter of the United Nations (Adopted in 26 June 1945, entry into force 24 October 1945) I UNTS XVI, art. 33.

81 See inter alia United States Diplomatic and Consular Staff in Tehran (United States of America v. Iran) [1980] (Judgment) ICJ Rep, p. 27 § 51; Aegean Sea Continental Shelf Case (Greece v. Turkey) 
generic clause differs from the bona fide negotiations of PIL in that (i) it provides a specific negotiation timetable that can range from three ${ }^{82}$ to $\operatorname{six}^{83}$ or up to eighteen ${ }^{84}$ months and, more importantly, (ii) it imposes an obligation, not a mere possibility, to engage in negotiations. ${ }^{85}$ Hence, the prior steps provided for in the generic clause of this work should not be confused with the ideal of international litigation of bona fide negotiations.

\section{B. Domestic litigation}

Both doctrine and case law have conflated the prior step of national litigation with the PIL rule of exhaustion of local remedies, ${ }^{86}$ and even certain BIT's contain this rule of exhaustion of local remedies explicitly. ${ }^{87}$ However, they are not the same. The exhaustion of local remedies prior to international litigation, unlike bona fide negotiations, is a rule of PIL, not a mere possibility or ideal. ${ }^{88}$ This rule derives from the doctrine of diplomatic protection. Its underlying logic is that whenever a foreigner is subject to the jurisdiction of a State and a legal dispute arises with the latter, the host State has the opportunity to resolve the dispute within its jurisdiction prior to international litigation. ${ }^{89}$ The rule presupposes that the alien individual willingly subjected himself to the jurisdiction of the receiving

[1978] ICJ Rep 3 § 29; Trial of Pakistan Prisoners ofWar (Pakistan v. India) [1973] ICJ Rep, p. 347.

82 Bernasconi-Osterwalder, N. \& Johnson, L., Commentary to the Austrian Model Investment Treaty (Study commissioned by the Chamber of Labour for Vienna, Austria Vienna, November 2011), p. 30.

83 German Model Agreement art. 11 UNCTAD Compendium, vol. III, 1996, p. 172; United States Model BIT, art. IX, UNCTAD Compendium, vol. III, 1996, p. 201.

84 Switzerland Model BIT, art. 8(1) 11 UNCTAD Compendium, vol. III, 1996, p. 181.

85 Murphy v. Ecuador, n. 78, § 132.

86 Schreuer, C., Calvo's grandchildren, n. 79.

87 Sornarajah, M., The International Law on Foreign Investment, Cambridge, CUP, 2004 [Hereinafter: Sornarajah, The International Law on Foreign Investment] pp. 254 y 255.

88 Interhandel Case, n. 26, p. 27; Elettronica Sicula S.p.A. (ELSI) (United States of America v. Italy) [1989] ICJ Rep; The Finnish Ships Arbitration (Finland v. United Kingdom), 1934, 3 UNRIAA [The Finnish Ships Arbitration]; The Ambatielos Claim (Greece v. United Kingdom), 1956, 12 UNRIAA, p. 83; Dodges, W., National Courts and International Arbitration: Exhaustion of Remedies and Res Judicata under Chapter 11 of NAFTA 23 HI\&CL 357, p. 361.

89 Mavromatis Palestine Concessions (n. 65); Sornarajah, The International Law on Foreign Investment (n.88) pp. 254-255. 
State..$^{90}$ Even if the logic of the prior steps stipulated in certain BIT's is similar, ${ }^{91}$ international investment arbitration is not diplomatic protection. By virtue of investor-State arbitration, the former claims the violation of certain standards of protection directly, not through his or her national State. ${ }^{92}$ Further, the domestic litigation established by the prior steps do not require the exhaustion of local remedies, but rather the litigation of the dispute for a specific period, regardless of whether the available remedies are exhausted. Moreover, a great amount of arbitration clauses in BIT's are made under the ICSID Convention, which excludes from arbitration any other remedy, unless otherwise stated..$^{93}$ Given all the aforementioned, it

90 Idem.

91 ICS v. Argentina (n.39) § 261.

92 Douglas, The International Law of Investment Claims, n. 16, p. 135. Recently, the debate concerning the nature of investors' rights in BIT's have gained much intensity. Particularly, it has been discussed whether such rights belongs directly to the investor, if they derive from rights originally proscribed for their national States, or whether they constitute rights conferred upon third parties to the BIT (the investors). The particular sentence from which this footnote derives does not constitute a statement in favor of any of the approaches to the investors' rights previously mentioned, since it is not the purpose of this work to take a position on such debate. For a detailed explanation on the different approaches and the debate in particular, see Loewen Group, Inc. and Raymond L. Loewen v. United States of America (Award) (ICSID Case No. ARB(AF)/98/3) (26 June 2003); Cargill, Incorporated v. United Mexican States (Award) (ICSID Case No. ARB(AF)/05/2) (18 September 2009); Corn Products International, Inc. v. United Mexican States (Decision on Responsibility) (ICSID Case No. ARB (AF)/04/1) (18 August 2008); Rudolf Braun, T. Globalization-Driven Innovation:The Investor as a Partial Subject in Public International Law - An Inquiry Into the Nature and Limits of Investor Rights (2013) Jean Monet Working Paper 04/13 NYU School of Law; Lossari, J. \& Ewing-Chong, M., Legitimate Countermeasures in International Trade Law and their Illegality in International Investment Law (2013) International Law Association Regional Conference 2013 | 29-31 August 2013, Cape Sounion, Greece (Draft available at http://cil.nus.edu.sg/wp/wp-content/uploads/2013/09/ JamesLosari-MEwing-Chow-Countermeasures-in-International-Trade-Law-Paper.pdf. Last visited: 14 May 2014); J D Fry \& O Repousis, Stripping the jurisdiction from established investment arbitral tribunals (2013) International Law Association Regional Conference 2013 | 29-31 August 2013, Cape Sounion, Greece (Resume available at http: / /www.ilaregional2013.gr/images/pdf/ abstract/30August/21.\%20James\%20Fry\%20abstract.pdf. Last visited: 15 May 2014); Gourgourinis, A., “ «Investors» Rights qua Human Rights? Revisiting the «Direct»/ «Derivative» Rights Debate", in Fitzmaurice, M. \& Merkouris, P., The Interpretation and Application of the European Convention of Human Rights Legal and Practical Implications, Martinus Nijhoff, 2012.

93 ICSID Convention (n. 57) art. 26. Pertaining to arbitration clauses in general, regardless of whether they consent to ICSID arbitration or not, a great debate has emerged on whether the exhaustion of local is still necessary whenever these clauses does not establish 
follows that domestic litigation, as a step prior to arbitration, is not the same as the rule of exhaustion of local remedies of PIL.

\section{Legal Interpretation of the Prior Steps to Arbitration}

With a basic understanding of the logic of the generic clause, it is relevant and necessary to clarify its meaning and scope. ${ }^{94}$ Since the generic clause is established in international treaties in terms of the 1969 Vienna Convention on the Law of Treaties (1969 Vienna Convention), ${ }^{95}$ its rules of interpretation are applicable, as either a treaty obligation or a customary rule of PIL. ${ }^{96}$

In the interpretation of jurisdictional clauses, in which the prior steps to arbitration are codified, no special rule of interpretation applies. ${ }^{97}$ Some

this rule explicitly. For reference on this debate, see Sornarajah, The International Law on Foreign Investment (n. 88) p. 254-255; Schwebel, S. \& Wetter, G., Arbitration and Exhaustion of Local Remedies (1966) 60 AJIL 484; Schwebel, S. \& Wetter, G., "Arbitration and the Exhaustion of Local Remedies Revisited”, in Festschrift for Joseph Gould, 1989.

94 For reference to cases where a method of interpretation has been applied to shed light on the meaning and scope of prior steps to arbitration and similar procedural requirements see inter alia BG Group v. Argentina (n. 8); Murphy v. Ecuador (n. 78); Ethyl Corp v. Canada (Award on Jurisdiction) (UNCITRAL) 38 ILM 708 [Hereinafter: Ethyl Corp v. Canada]; Wintershall v. Argentina (n. 73); Maffezini v. The Kingdom of Spain (Decision of the Tribunal on Objections to Jurisdiction) (ICSID Case No. ARB/97/7) (2000) [Hereinafter: Maffezini v. Spain].

95 UNGA Vienna Convention on the Law of Treaties (Adopted in 22 May 1969, entry into force 27 January 1980) 1155 UNTS 331 [Hereinafter: 1969 Vienna Convention] art. 1(1)(a).

96 Oil Platforms (Islamic Republic of Iran v. United States of America) [1996] (Preliminary Objections) ICJ Rep 803 p. $812 \S 23$; Case Concerning Kasikili/Sedudu Island (Botswana v. Namibia) [1999] (Merits) ICJ Rep 1045 p. 1059 § 18; Sovereignty over Pulau Ligitan and Pulau Sipadan (Indonesia v. Malaysia) [2002] (Merits) ICJ Rep 682 [Hereinafter: Sovereignty over Pulau Ligitan and Pulau Sipadan] p. 645 § 37; Romak S. A. (Switzerland) v. the Republic of Uzbekistan (Award) (PCA Case No. AA280) $\S \S 169,172$; National Grid plc v. The Argentine Republic (Decision on Jurisdiction) (UNCITRAL) (20 June 2006) § 51; Canfor Corporation v. United States of America, Tembec Inc., Tembec Investments Inc. and Tembec Industries Inc. v. United States of America, and Terminal Forest Products Ltd. v. United States of America (Order of the Consolidation Tribunal) (UNCITRAL) (7 September 2005) § 59; Herdegen. M., Interpretation in International Law, The Max Planck Institute of International Law, Rüdiger Wolfrum, 2008, § 1.

97 Mondev International Ltd v. United States (Award) (ICSID Case No. ARB(AF)/99/2) (11 October 2002) [Hereinafter: Mondev v. USA] § 43; SOABI v Senegal (Award) (2 ICSID Report 1983) p. 393, 397; Ethyl Corp v. Canada (n. 95) § 55; Austrian Airlines v. Slovak Republic (UNCITRAL) (20 October 2009) §§ 119-121; Telenor Mobile Communications A.S. v. The Republic of Hun- 
States and tribunals have asserted that these clauses should be interpreted restrictively per special rules..$^{98}$ Meanwhile, investors have argued that they should be interpreted extensively also based on special rules of interpretation. ${ }^{99}$ However, these approaches have been rejected by both doctrine and case law. ${ }^{100}$ The arbitral tribunal in Daimler v. Argentina stated that "[i]n interpreting dispute resolution provisions in BITs — just as with any other treaty provision — the ultimate goal is to determine what the contracting parties actually consented to... To go beyond those bounds would be to act ultra vires". ${ }^{101}$ Therefore, the general rules of interpretation of articles 31 and 32 of the 1969 Vienna Convention apply to interpret the generic clause.

In international law, there is precedent for one single interpretation to be extended to a group of several jurisdictional clauses - provided that they all have the same or similar meaning. The ICJ, in its decision on the Case Concerning Armed Activities on the Territory of the Congo analyzed the fulfillment of the prior steps to adjudication of the dispute codified in four different international treaties. ${ }^{102}$ Although none of these clauses were identical, they all established the need for fulfillment of prior steps to adjudica-

gary (Award) (ICSID Case No. ARB/04/15) (13 September 2003) § 89-90; C De Visscher, Theory and reality in public international law (New Jersey, Princeton, 1968), p. 395.

98 U.S.A. v. The Islamic Republic of Iran [1984] US-Iran CRT, p. 99; The Government of the Islamic Republic of Iran v. The Government of the U.S.A. (1984), US-Iran CRT, p. 80; Southern Pacific Properties (Middle East) Ltd. v. Arab Republic of Egypt (Decision on Jurisdiction II) (ICSID Case No. ARB/84/3) (14 April 1988); Lalive, P., “The First World Bank Arbitration (Holiday Inns v Morocco) - Some Legal Problems”, 51 British Yearbook of International Law, 1980, pp. 153, 158; Dolzer, R., "The Notion of Investment in Recent Practice”, in Charmovitz et al. (eds.), Law in the Service of Human Dignity: Essays in Honour of Florentino Feliciano, CUP, 2005, pp. 274-275.

99 Holidays Inns v. Morocco (1 ICSID Reports 674).

100 Mondev v. USA (n. 98) § 43; Amco v. Indonesia (n. 15) p. 394; Ethyl Corp v. Canada (n. 95) $\S 55$; Case concerning the Aerial Incident of 10 August 1999 (Pakistan v. India) [2001] ICJ Rep 12 $\S 42$; Fisheries Jurisdiction Case (Spain v. Canada) [1998] ICJ Rep 432 at pp. 451-2 §§ 37-38, 44-56; Schreuer, C., Diversity and Harmonization of Treaty Interpretation in Investment Arbitration (2006) 3 TDM 2, p. 4.

101 Daimler v.Argentina (n. 59) § 172.

102 Article 29 of the Convention on the Elimination of All Forms of Discrimination against Women; Article 75 of the World Health Organization (WHO) Constitution; Article XIV, paragraph 2, of the Constitution of the United Nations Educational, Scientific and Cultural Organization of 16 November 1945; Article 14, paragraph 1 of the Montreal Convention for 
tion, as does the generic clause, mutatis mutandis. ${ }^{103}$ For the ICJ it sufficed to interpret one clause to determine in genere purpose of all the clauses and then analyze whether each of these conditions was fulfilled.

Most importantly, in the Case Concerning Application of the International Convention on the Elimination of All Forms of Racial Discrimination ("Georgia V Russian Federation Case"), the ICJ stated that:

Though similar in character, compromissory clauses containing a reference to negotiation (and sometimes additional methods of dispute settlement) are not always uniform... The Court observes that in each of the above-mentioned cases where the compromissory clause was comparable to that included in [the relevant Convention], the Court has interpreted the reference to negotiations as constituting [the same obligation]. ${ }^{104}$

The ICJ's language demonstrates that the interpretation of a single jurisdictional clause can be applied to several clauses whenever they have a similar meaning.

Under the rules of PIL codified in articles 31 and 32 of the 1969 Vienna Convention, treaties must be interpreted in good faith and in accordance with the intention of the parties as expressed in the ordinary meaning of the terms, its context and purpose. ${ }^{105}$ In order to confirm the result obtained in this method of interpretation or if this result is too ambiguous or manifestly absurd and unreasonable, recourse may be made to supplementary means of interpretation ${ }^{106}$ such as taking into account the travaux préparatoires of the treaty. ${ }^{107}$

the Suppression of Unlawful Acts against the Safety of Civil Aviation of 23 September 1971; Armed Activities on the Territory of the Congo (n. 14) §§ 81-119.

103 Ibidem, $\S \S 81,100,108,110$.

104 Georgia v. Russian Federation Case (n. 51) §§ 136, 140.

1051969 Vienna Convention (n. 96) art 31(1); H Lauterpacht, Restrictive Interpretation and the Principle of Effectiveness in the Interpretation of Treaties (1949) 26 British Yearbook of International Law 48; Territorial Dispute (Libya v Chad) [1994] Judgment ICJ Rep 6 § 41; Le Royaume du Belgique c. Le Royaume du Pays Bas (Sentence du Tribunal Arbitral) (CPA) (24 mai 2005) § 47.

106 Territorial Dispute (Libyan Arab Jamahiriya /Chad) [1994] (Judgment) ICJ Rep, p. 27 § 55; Qatar and Bahrain case (n. 50) p. 21, § 40; Sovereignty over Pulau Ligitan and Pulau Sipadan (Indo-

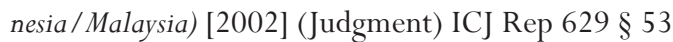

1071969 Vienna Convention (n. 96) art. 32. 
Regarding the interpretation of clauses providing for prior steps to international adjudication, the ICJ's decision in the Georgia v Russian Federation Case is distinctly important. The Court interpreted Article 22 of the International Convention on the Elimination of All Forms of Racial Discrimination (“CERD”). ${ }^{108}$ The article provides that:

Any dispute between two or more States Parties with respect to the interpretation or application of this Convention, which is not settled by negotiation or by the procedures expressly provided for in this Convention, shall, at the request of any of the parties to the dispute, be referred to the [ICJ] for decision, unless the disputants agree to another mode of settlement. ${ }^{109}$

To clarify the legal meaning of the prior steps set forth in this Article, the Court referred to the ordinary meaning of its terms. ${ }^{110}$ In particular, based on the principle of effet utile, ${ }^{111}$ the Court stated that the heavily debated phrase "any dispute which is not settled" called for the parties to mandatorily resort to such prior mechanisms to settle the dispute. ${ }^{12}$

The Court found that the application of the basic rules of treaty interpretation sufficed to demonstrate that the juridical meaning of the clause was that the prior steps where mandatory; recourse to the travaux préparatoires as a supplementary mean of interpretation was thus unnecessary. ${ }^{113}$ It only analyzed them under the express request of the parties, ${ }^{114}$ and the ICJ ruled that unless the travaux explicitly provide for the non-mandatory

108 Georgia v. Russian Federation Case (n. 51).

109 International Convention on the Elimination of all Forms of Racial Discrimination (Adopted 25 December 1965, entry into force 4 January 1969) 660 UNTS 195, art. 22.

110 Georgia v. Russian Federation Case (n. 51) $\$ \S 123-141$.

$111 \mathrm{Ibidem}, \S 133$. On the application of this principle of treaty interpretation, see also Free Zones of Upper Savoy and the District of Gex, Order of 19 August [1929] PCIJ, Series A, No. 22, p. 13; Corfu Channel (United Kingdom v. Albania) [1949] (Merits, Judgment) ICJ Rep, p. 24; Territorial Dispute (Libyan Arab Jamahiriya / Chad) [1994] (Judgment) ICJ Rep, p. 25 § 51; EurekoV.B. v. Republic of Poland (Partial Award) (ICSID) (19 August 2005) § 248; Pan American Energy LLC and BP Argentina Exploration Company v.Argentine Republic (Decision on Preliminary Objections) (ICSID Case No. ARB/03/13) (27 July 2006) § 132.

112 Georgia v. Russian Federation Case (n. 51) § 133 in fine.

113 Ibidem, $§ 142$.

114 Idem. 
character of the prior steps, the initial legal meaning given by the Court prevails. ${ }^{115}$

The generic clause provides:

Any dispute relating to an investment shall be negotiated or submitted to the decision of a competent domestic court of the Host State of the investment. Such disputes shall be submitted to arbitration whenever (i) 6 months have elapsed since the beginning of the negotiations; or (ii) after a period of 18 months starting form the moment in which the dispute was submitted to the competent domestic court of the Host State of the investment and such court has not rendered its final decision, or (iii) whenever the latter has rendered a decision but the dispute remains.

Although the phrase "any dispute which is not settled" does not appear in the clause at hand, the mandatory nature of the prior steps to arbitration, and of all jurisdictional clauses containing similar provisions, such as article 22 of the CERD, remains. ${ }^{116}$ The ordinary meaning of the terms of the clause is that generic negotiation or litigation for six months or eighteen months, respectively, are sine qua non conditions for seeking recourse to international arbitration. This is evidenced by the fact that it provides that the parties shall, not may, meet these requirements prior to the institution of arbitration. ${ }^{117}$ This has also been the interpretation given by various tribunals when considering similar provisions. ${ }^{118}$

Moreover, as established by the ICJ in the Georgia $v$ Russian Federation Case, interpreting the opposite - i.e. that these prior steps are not mandatory — could lead per se to an absurd result and, therefore, affront against

115 Ibidem, $\$ 143$.

116 Actually, in the Georgia v Russian Federation Case, this phrase determined the result achieved by the Court since the fact that a dispute prevails or not depended on such phrase. Normally, if a dispute is settled it no longer exist. In the generic clause of this work, the interpretation of the existence of a dispute is broader. The relevant point to address is that the fact that the dispute is already settled or not is irrelevant here. What it is important is to determine whether the prior steps to arbitration are mandatory or not. This was a fundamental point in the decision of the ICJ in Georgia v Russian Federation Case (n. 51) and Armed Activities on the Territory of the Congo (n.14), previously cited.

117 Maffezini v Spain (n. 95); Bayindir v. Pakistan (n. 58); Wintershall v. Argentina (n. 73); ICS v. Argentina (n. 39); Daimler v. Argentina (n. 59).

118 See footnote 77 above. 
the principle of pacta sunt servanda and effet utile: ${ }^{119}$ the possibility of negotiating a dispute or litigating it in domestic courts, prior to international arbitration, always exists. There is no need to expressly agree to it in arbitration clauses. Thus, the purpose of establishing them in jurisdictional clauses is to transfer these dispute settlement mechanisms from the facultative scheme to the imperative realm.

In order to determine whether these prior steps were actually fulfilled: if they refer to prior litigation in domestic courts, then the dispute must be submitted and actually litigated in the local instances during the time stipulated. The fulfillment of this step depends on municipal laws that regulate the particular dispute. As for the negotiations, they must consist of more than mere opposition to differing factual and legal points of view of a given situation. ${ }^{120}$ They require at least a genuine attempt to undergo discussions with the aim of settling the dispute. ${ }^{121}$

\section{Legal Value of the Prior Steps to Arbitration: THE Approaches}

\section{Admissibility}

Before presenting the proposed approaches to determine the legal value of the prior steps to arbitration, it is important to present the general position that other tribunals have taken in this regard.

Certain case law and publicists have advanced that these prior steps does not represent an obligation for the claimant. ${ }^{122}$ Furthermore, and sometimes by virtue of this, they have found that the legal nature of the prior steps is of admissibility, not jurisdictional or of seisin. ${ }^{123}$ Consequently, in

119 Georgia v. Russian Federation Case (n. 51) § 134.

120 Fisheries Jurisdiction Case (Germany v. Iceland) [1974] ICJ Rep 3, p. 201.

121 Ibidem § 157; North Sea Continental Shelf (Federal Republic of Germany/Denmark; Federal Republic of Germany/Netherlands) [1979] ICJ Rep 3, p. 48 § 87; Railiway Trafic between Lithuania and Poland (Advisory Opinion) [1931] PCIJ Series A/B, No. 41, p. 116.

122 Biwater Gauff v. Tanzania (n. 2) § 343; Abaclat v. Argentina (n.2) §§ 577-590; Bayindir v. Pakistan (n. 58) § 102. See in general Dolzer, R. \& Schreuer, C., Principles of International Investment Law, OUP, 2012, pp. 170-172.

123 In general, the tribunals have concluded this without giving a clear explanation on why the prior steps are an issue of admissibility of a claim. For instance, in the Abaclat case, 
the presence of non-compliance with these prior steps, the tribunals that have taken this perspective, have proceed to deal with the merits of the case since obliging the claimant to comply with the prior steps would be overly formalistic, absurd or ineffective once the arbitration has commenced. ${ }^{24}$

With regards to this position, to determine if the prior steps are truly mandatory or not, special attention has to be taken to the terms of the treaty. Concerning the characterization of these same steps as admissibility issues, it must be remarked that admissibility issues concern a particular claim. Conversely, since the prior steps shapes and limits the State's consent, they affect the whole application. In this vein, the ICJ determined that "any conditions to which such consent is subject must be regarded as constituting the limits thereon. The Court accordingly considers that the examination of such conditions relates to its jurisdiction and not to the admissibility of the application” ${ }^{125}$ (Emphasis added).

absent this explanation, the objection on the failure to comply with the prior steps was classified as an admissibility objection, as can be evidenced by the index of the case, pp. 4-5. See, similarly, Antoine Goetz c Burundi (n. 59) § 90. In the Ethyl Corp v. Canada case the tribunal established that the fulfillment of prior steps to arbitration - in that case, genuine "cooling off periods" - were issues "that must be satisfied by Claimant, but the failure to satisfy which results not in the absence of jurisdiction $a b$ initio, but rather in a possible delay of proceedings, followed ultimately, should non-compliance persist, by dismissal of the claim” $§ 58$. In accordance to what has been previously explained, this definition refers to matters of admissibility of a claim. The paragraph containing this statement have been cited by several tribunal while determining the legal nature of prior steps to arbitration and the legal consequences of their non-compliance: SGS v. Pakistan (n. 2) § 184; Ronald S. Lauder v. The Czech Republic (Award) (UNCITRAL Case) (3 September 2001) [Hereinafter: Ronald S. Lauder v. The Czech Republic] § 187. Also, although the tribunal in Biwater Gauff v. Tanzania never clearly establishes whether the prior steps are jurisdictional and admissibility issues, it cites inter alia the Ethyl Corp v. Canada and Ronald S. Lauder v. The Czech Republic to reinforce its decision. See $\$ \S 346-273$. See in this same vein, Sergei Paushok, CJSC Golden East Company and CJSC Vostokneftegaz Company v. The Government of Mongolia (Decision on Jurisdiction and Liability) (UNCITRAL) (28 April 2011) § 220. The tribunal in BG Group v. Argentina treated the prior steps as issues of admissibility of a claim, without clearly establishing the reasons why. However, the Respondent in this case argued that these prior steps were indeed admissibility issues. See $\S 141$. See also the arguments raised by the Democratic Republic of the Congo in Armed Activities on the Territory of the Congo (n.14) §88.

124 Abaclat v.Argentina (n. 2) §§ 577-590; TSA Spectrum v.Argentina (n. 2) § 112; SGS v. Pakistan (n. 2) § 184; Bayindir v. Pakistan (n. 58) § 102; Ronald S. Lauder v. The Czech Republic (n. 124) $\S 181 ;$ BG Group v.Argentina (n.8) §§ 147-156; Ethyl Corp v. Canada (n. 95) § 84.

125 Armed Activites in the Territory of the Congo (n. 14) $\S 88$. See also in this same sense Ma- 
This statement is correct and has been echoed in ILFI. ${ }^{126}$ However, the approaches proposed here provide an independent explanation as to why the failure to meet the prior steps to arbitration is a matter of jurisdiction of the tribunal, not of the admissibility of a claim.

\section{A. The Rejected Offer to Arbitrate}

Under the first approach, the prior steps to arbitration contained in the generic clause, and other similar compromissory clauses of BIT's, represent the terms of the offer to arbitrate made by the host State. By failing to meet them, the investor implicitly rejects the offer of the State and, consequently, there is no arbitration agreement between the parties. ${ }^{127}$ For instance, in her well-known dissenting opinion to the case of Impregilo $\operatorname{SpA}$ v. Argentina, Professor Brigitte Stern established that “... the State can shape [its] consent as it sees fit, in providing for the [ratione voluntatis] conditions under which such an "offer to arbitrate" is made to the foreign investors". ${ }^{128}$ Likewise, the tribunal in Wintershall v. Argentina determined that the prior steps to arbitration constitute an integral part of the "standing offer"... of the Host State, which must be accepted on the same terms by every individual investor who seeks recourse (ultimately) to ICSID arbitration”. ${ }^{129}$ This

vromatis Palestine Concessions (n.65) pp. 11-15; Interpretation of the Statute of the Memel Territory [1932] (Merits, Judgment) PCIJ, Series A/B, No. 49, pp. 327-328; Electricity Company of Sofia and Bulgaria [1939] (Judgment) PCIJ, Series A/B, No. 77, pp. 78-80; Border and Transborder Armed Actions (Nicaragua v. Honduras) [1988] (Jurisdiction and Admissibility, Judgment) ICJ Rep, pp. 88-90 §§ 42-48; Kiliç v. Tuknemistan (n.77) § 6.3.15.

126 In his Dissenting Opinion in Abalclat v.Argentina, Professor Abi-Saab established that "[a] ny limits to this power, whether inherent or consensual, i. e. stipulated in the jurisdictional title (consent within certain limits, or subject to reservations or conditions relating to the powers of the organ) are jurisdictional by essence". See Dissenting Opinion of Professor Georges Abi-Saab (n.77) § 126.

127 Bg Group PLC Petitioner v. Republic of Argentina 572 U. S. Supreme Court of the United States (2014) (No. 12-138) (4 March 2014) (Chief Justice Roberts, with whom Justie Kennedy Joins, dissenting), at 5-6; Dugan, C. et al., Investor-State Arbitration, OUP, 2008, p. 221; Salacuse, J., The Law of Investment Treaties (OUP, 2010), p. 381; BG Group PLC v. Republic of Argentina No. 12-138 Supreme Court of the United States (Brief of Amicus Curiae of Practitioners and Professors of International Arbitration Law in Support of Respondent), p. 5.

128 Impregilo S.p.A. v. Argentine Republic (Concurrent and Dissenting Opinion of Professor Brigitte Stern) (ICSID Case No. ARB/07/17) (21 June 2011) § 53.

129 Wintershall v.Argentina (n.73) $§ 160$. 
approach has been echoed by case law and is based on the premise that the prerequisites for arbitration are ratione voluntatis conditions of the consent given by the State. ${ }^{130}$

Based on this approach, the effects of the failure to meet the prior steps go directly to the jurisdiction strictu sensu of the tribunal, since the matching consent of the parties to arbitrate the dispute never actually existed. What did exist was an open offer, which only per full acceptance of its terms and conditions becomes an arbitration agreement. This agreement would represent the match between the State's and the investor's consent and ergo the tribunal's jurisdiction arises. If the prior steps are not met, and the investor submits its claim to an international tribunal, there is only the consent of the investor, on the one hand, and an open offer of the State, on the other.

\section{B. Conditions of Seisin}

Under this second approach, at the time an investor notifies the host State of its intention to arbitrate, there is consent in strict terms of both the former and the latter to seek recourse to arbitration. However, for such consent to have legal effects, it must meet the prior steps for arbitration ${ }^{131}$ that, therefore, represent the conditions of seisin of the arbitral tribunal. ${ }^{132}$

Failure to comply with the prior steps to arbitration is not relevant to the admissibility of the claim submitted, but rather to the tribunal's jurisdiction to rule on the merits of the dispute. This, not by virtue of the fact

130 Philip Morris Brands SÀRL and others v Uruguay (Decision on Jurisdiction) (ICSID Case No ARB/10/7) (2 July 2013) § 33.

131 This sort of legal analysis - that the legal effects of a certain right or obligation are subjected to the fulfillment of a condition - is no strange for the ICJ. For instance, in the Nottebohm, the Court stated that whenever declarations recognizing the jurisdiction of the Court exists between two parties of a dispute "the filing of the Application is merely the condition required to enable the [declarations] to produce [their] effects". Nottebohm (Liechtenstein $v$ Guatemala) (Preliminary Objection (including the text of the declaration of Judge Klaestad) [1953] ICJ Rep 4 [Hereinafter: Nottebohm (Liechtenstein v Guatemala) (Preliminary Objection (including the text of the declaration of Judge Klaestad)] p. 123.

132 The tribunal in the Hotchief case acknowledged that the prior steps to arbitration were conditions of its seisin. However, it found that they could be ignored by the application of a Most Favoured Nation clause. Hochtief AG v Argentina (Decision on Jurisdiction) (ICSID Case No ARB/07/31) (24 October 2011) §99. 
that the juridical value of the prior steps is jurisdictional strictu sensu: the consent to arbitrate the dispute exists and hence there is an attribution de la jurisdiction. Nonetheless, this consent is subject to mandatory conditions. ${ }^{133}$ For the consent to have legal effects and the tribunal to be competent to deal with the case, the investor must perform some preliminary actions: negotiate or litigate the dispute in domestic courts for a period of time. It follows that in reality these clauses are conditions for the seisin of the relevant adjudicative organ. ${ }^{134}$ Hence, their legal value is of seisin and the result of their non-compliance is a lack of jurisdiction strictu sensu by virtue of the fact that the consent of the parties has no legal effect although it does exist. The ICJ has reached the same conclusion in its most recent decisions. ${ }^{135}$ And, as previously stated, and keenly propounded by Sir Gerald Gray Fitzmaurice, if these steps are not met, then there is no valid seisin of a court or tribunal, and the tribunal has no jurisdiction whatsoever to resolve the case submitted. ${ }^{136}$ Jurisdiction is nothing without the valid act of seisin that renders it possible. ${ }^{137}$

The two proposed approaches are not so different. Actually, their difference is a matter of perspective: one is focused on the investor, and the other on the tribunal. Notwithstanding, their essential character is that the prior steps to arbitration are mandatory, not optional. Ultimately, whether the offer to arbitrate or the conditions for seisin are argued, the legal result would be that the tribunal should dismiss the case for lack of jurisdiction strictu sensu at the relevant procedural time: under the first approach, since no matching consent between the parties existed, and under the second approach, since the consent of the parties has no legal effect.

133 See inter alia, Maffezini v. Spain (n.95); Wintershall v. Argentina (n.73); ICS v. Argentina (n.39); Daimler v. Argentina (n.59); Kiliç v. Tuknemistan (n.77); Armed Activities on the Territory of the Congo (n.14); Georgia v. Russian Federation Case (n.51).

134 Douglas, The International Law of Investment Claims (n.16) p. 160.

135 Armed Activities on the Territory of the Congo (n.14); Georgia v. Russian Federation Case (n. 51).

136 Fitzmaurice, G., The Law and Procedure of the International Court of Justice (1986), British Yearbook of International Law, p. 440.

137 Weil, P., Compétence et saisine: un nouvel aspect du principe de la jurisdiction consensuelle (n. 40) p. 841; Douglas, The International Law of Investment Claims (n.16). 


\section{Factual and Legal Consequences of Failure to Meet the Prior Steps to Arbitration}

\section{a. Legal Consequences}

The tribunal cannot exercise jurisdiction over the dispute under either scenario. Furthermore, in the case of invalid seisin, some scholars have stressed that the tribunal would even lack compétence de la compétence to rule on its jurisdiction: the seisin is the first act performed before the tribunal at a dispute; it turns on the tribunal's switch, in the words of Hugh Thirlway. ${ }^{138}$ Immediately after valid seisin is established, the tribunal can then exercise its compétence de la compétence. ${ }^{139}$ But, as some counsels have suggested, if the seisin is invalid, then no switch is activated and the machinery of the tribunal did not start, not even its compétence de la compétence. ${ }^{140}$ The ICJ ruled

138 Thirlway. H., The Law and Procedure of the International Court of Justice (n. 41) p. 39.

139 In other words, to analyze whether it possesses (i) the power to examine whether it has jurisdiction in the case, (ii) the power to decide on the admissibility of the claim, and (iii) in some cases, the power to decide on the merits. See L Boisson de Chazournes, "The principle of Compétence de la Compétence' in International Adjudication and its Role in an Era of Multiplication of Courts and Tribunals", in Arsanji, M. H. et al. (eds.), Looking to the Future: Essays on International Law in Honor ofW. Michael Reisman, Leiden, Martinus Nijhoff, 2011, p. 1027.

140 This discussion was presented by Serbia (the former Federal Republic of Yugoslavia) in the cases submitted against it by Bosnia \& Herzegovina, and Croatia in the Application of the Genocide Convention before the ICJ. Serbia advanced inter alia that the Court did not enjoy compétence de la compétence in these cases since at the moment of the filing of the application on each case, Serbia was not a party to the Statute of the Court, which, according to Serbia, is an element of seisin of the ICJ. The Court argued that in its decision on the Legality of Use of Force cases between Serbia and several members of the North Atlantic Treaty Organization it established that the former became a member of the Statute in 2000 — prior to the decision of the Application of the Genocide Convention, but after the filing of the application in that caseand, therefore, at the moment of its decision, the Court did enjoy compétence de la compétence. I believe the argument is inaccurate. Regardless of whether an invalid seisin could amount to a lack of compétence de la compétence of the Court, the fact that a State is party or not to the Statute is not a condition of seisin of the ICJ. For this and many other reasons, the decision of the Court in these cases has been heavily criticized. See Y Z Blum, Note and Comment: Consistently Inconsistent: The International Court of Justice and the Former Yugoslavia (Croatia v. Serbia), (2009) 103 AJIL 264; H Thrilway, The Law and Procedure of the International Court of Justice, pp. 42-43; Application of the Genocide Convention (Croatia v. Serbia) [2008] ICJ Rep 441-442 § 86; Legality of Use of Force (Serbia \& Montenegro v. Belgium) (Preliminary Objections) [2004] ICJ Rep 279 , p. $299 \S 46$. 
thusly in the Nottebohm case that "when... the condition required to enable the clause of compulsory jurisdiction to produce its effects... the Court... has jurisdiction to deal with all [the] aspects [of the claim] whether they relate to jurisdiction, to admissibility or to the merits". ${ }^{141}$ Only from the exercise of compétence de la compétence, can a judge or arbitrator examine whether or not there was a valid seisin. If there is no real compétence de la compétence in the presence of invalid seisin, such invalidity must be explicit and without need for further analysis. In practice, this scenario is very unlikely. Consequently, it has been advanced that the mere fact that the parties litigate the compliance with the prior steps to arbitration constitutes a granting of compétence de la compétence to rule on that point exclusively. ${ }^{142}$

In the case of rejection of the arbitration offer, a different argumentative logic arises since, as aforementioned, the investor rejects the terms and conditions of the offer - and the offer itself - and activates motu propio another arbitration proceeding under its own terms and absent of any mandatory condition of seisin. Then there would be no obstacle to the tribunal's exercise of its compétence de la compétence. Nonetheless, the court should find a lack of jurisdiction ratione voluntatis since the respondent State did not agree to arbitrate the dispute under the terms on which the investor did.

Accordingly, the central point of discussion regarding the lack or absence of compétence de la compétence is that while in one case the investor initiates an arbitration under its own terms and rejects the State's offer, in the other the investor intends to continue acting under the terms of the arbitration clause but fails to meet them. At the end of the day, in practical terms the tribunal must exercise analyze effectively if (i) the prior steps to arbitration are fulfilled and, based on that analysis, (ii) if the tribunal can rule on the merits of the dispute. Under both approaches - the rejected offer and the conditions for seisin - if the first analysis yields a negative result, the second shall be negative as well: no jurisdiction arises, either because no arbitration agreement existed or because there was an invalid seisin.

141 Nottebohm (Liechtenstein v Guatemala) (Preliminary Objection (including the text of the declaration of Judge Klaestad) (n.132) p. 123.

142 If the tribunal concludes that there was a valid seisin, then it could exercise its compétence de la compétence and deal with the preliminary objections concerning its jurisdiction and the admissibility of a claim, thereafter. 


\section{b. Factual Consequences}

Investors that ignore the prior steps to arbitration must fulfill them even after initiating arbitral proceedings. Only after meeting a high standard of proof of the futility of the prior steps, they shall they be exempted from this. Professor Schreuer argues that if the prior steps to arbitration can be fulfilled after the arbitration proceedings have begun - for example, to spend eighteen months of domestic litigation - the tribunal would have no reason to declare itself incompetent at the time the dispute is submitted even though no prior steps were met ${ }^{143}$ given that the investor will only have to wait for the established period of time of prior steps to elapse and, then, start another arbitration proceeding, which is inefficient. ${ }^{144}$ This argument departs from the premise that the prior steps have no greater purpose than the lapse of time. ${ }^{145}$ Nonetheless, Schreuer's conclusion does not appear valid since the actual goal of the prior steps in question is to settle the dispute by other means, not through the mere passage of time. So obliging the investor to withdraw its claim and to meet the prerequisites could result in settling the dispute and would be in conformity with the true intention of the parties to the BIT. ${ }^{146}$ Thus, to act as proposed by Shcreuer could turn even contrary to the will of the parties.

143 C Schreuer, At what time must jurisdiction exist? (Forthcoming) (Available at http: / /www. univie.ac.at/intlaw/wordpress/wp-content/uploads/2014/01/At-what-Time-Jurisdiction.pdf. Last visited 6 June 2014), p. 10.

144 Idem.

145 This is evident particularly due to the cases cited by Schreuer to sustain its position. As a starting point, it cites the ICJ's Mavromatis Palestine Concessions decision, where the Court dismissed a jurisdictional objection in light of its overly formalistic nature. Therefore, Professor Schreuer cited a jurisprudence constante of the ICJ in this sense and criticizes its decision in Georgia v. The Russian Federation case for departing from it. However, the previous case did not depart from the ICJ's criteria. The rejection of overly formalistic preliminary objections is still a practice in the ICJ. The decision in Georgia v. The Russian Federation case is the exception that confirms such rule: whenever the prior steps go beyond the mere form and have an actual potential of settling the dispute as such, they must be respected. The same occurs with the prior steps to arbitration cited by Schreuer: in all of them there is an ex ante presumption that they will fail to settle the dispute or they are overly formalistic, which is not necessarily accurate.

146 See Hochtief AG v. The Argentine Republic (Dissenting Opinion of J. Christopher Thomas Q.C.) (ICSID Case No. ARB/07/31) (7 October 2011) [Hereinafter: Dissenting Opinion of J. Christopher Thomas Q.C.] $\S 8$. 
In a similar vein, scholars and counsels have consistently maintained that even if working under the assumption that the prior steps in question are conditions of consent or jurisdictional elements, the factual context under which they must be fulfilled renders them futile. ${ }^{147}$ For example, during the Argentinian economic crisis — from which many investment cases emerged — ${ }^{148}$ that country declared a state of emergency and suspended all domestic legal proceedings against it. In this context, ordering a claimant investor to withdraw its arbitration claim to fulfill with the prior steps to arbitration - e.g. litigation in domestic courts - would not only be costly, ${ }^{149}$ but most probably useless. ${ }^{150}$

Thus the argument that the prior steps are futile seems valid. Indeed, in diplomatic protection, the exhaustion of local remedies is exempted whenever they result futile. ${ }^{151}$ However, in practice, this defense has worked in extreme cases - whenever it is demonstrated that the remedies are inaccessible or ineffective, or if further damage will be caused by exhausting the remedies. ${ }^{152}$ As accurately stated by Christopher Thomas, "[i]t is one

147 Schreuer. C., OfWaiting Periods (n. 76) p. 239; C Schreuer, Calvo's grandchildren (n. 79); BG Group v Argentina (n. 8); Wintershall v. Argentina (n. 73); Murphy v. Ecuador (n. 78); SGS v. Pakistan (n. 2); Daimler v. Argentina (n. 59); Bayindir v. Pakistan (n.58); Ronald S. Lauder v. The Chzech Republic (n.124).

148 See for instance J E Alvarez \& K Khamsi, 'The Argentinian Crisis and Foreign Investors', in Sauvant, K. P. (ed.), International Investment Law and Policy 2008 /2009 (OUP, 2009); L E Peterson, Argentina by the numbers: where things stand with investment treaty claims arising out of the Argentine financial crisis (1 February 2011) (Available at http://www.iareporter.com/ articles/20110201_9. Last visited 10 June 2014).

149 For reference on the costs of international investment arbitration, see Investor-State Disputes Arising from Investment Treaties: A Review, UNCTAD Series on International Investment Policies for Development (2005) (Available at www.unctad.org/en/docs/iteiit20054_en.pdf. Last visited: 20 February 2014), p. 8; Sinclair, A., ICSID Arbitration: How long does it take? (2009) 4 GARJ 5; Daimler v. Argentina (n.59) § 245.

150 Schreuer relies heavily on this point to determine the legal value of the negotiations prior to arbitration. Furthermore, it must be borne in mind that this is the exception that confirms the rule of exhaustion of local remedies in PIL.

151 Paulsson, J., Denial of Justice in International Law, CUP, 2005, p. 101-102; Amerasinghe. C. F., Local Remedies in International Law, CUP, 2005 [Hereinafter: Amerasinghe, Local Remedies in International Law], pp. 2004-2005.

152 For cases where it was found that the remedies where unavailable and inaccessible, see Communication No. 8/1977, Human Rights Committee Selected Decisions, p. 48; Communication No. 28/1978, Human Rights Committee Selected Decisions, pp. 58-9; Communication No. 44/1979, Human Rights Committee Selected Decisions, pp. 77 and 79. With regards to 
thing to determine, based on evidence, that the submission of a particular dispute to the local courts would be futile [and i]t is... quite another thing to make a rather sweeping judgment as to a treaty provision's utility based on a "worst-case" scenario of an assumed useless and expensive recourse to the local courts". ${ }^{153}$ (Emphasis added). The futility of local remedies must be demonstrated beyond reasonable doubt ${ }^{154}$ and the burden of proof, under the principle of onus probandi incumbit actori, lies on the investor. ${ }^{155} \mathrm{To}$ illustrate the problem of the high standard of proof of the futility of prior steps to arbitration, not even the measures taken by Argentina during the economic crisis $^{156}$ were considered to necessary render its domestic remedies futile. ${ }^{157}$

the ineffectiveness of a remedy, see The Finnish Ships Arbitration (n. 89) p. 1495. Pertaining to cases where recourse to further remedies will produce an injury to the claimant see in general USA v. Panama (1934) 28 AJIL, p. 607. For a comprehensive explanation of these and other limitations to the rule of exhaustion of local remedies, see Amerasinghe, Local Remedies in International Law (n. 152) pp. 200-216.

153 Dissenting Opinion of J. Christopher Thomas Q.C. (n. 147) § 10. See also Kiliç v. Tuknemistan (n.77) § 6.5.4.

154 Amerasinghe, Local Remedies in International Law (n. 152) p. 337. This is one of the highest standard of proof in international and national proceedings. See C F Amerasinghe, Evidence in International Litigation, Martinus Nijhoff Publishers, 2005, pp. 232-235. In international litigation, there are other standards of proof that depend on the fact of the case. For instance, there are less severe standards such as the convincing proof, evidence preponderance and reasonable conclusion inter alia. See Ibidem, pp. 232-258.

155 ICS v. Argentina (n. 39) § 280. See also Tradex Hellas S.A. v. Republic of Albania (Decision on Jurisdiction) (ICSID Case No. ARB/94/2) (24 December 1996); Pulp Mills on the River Uruguay (Argentina v. Uruguay) [2010] ICJ Rep (I), p. $71 \S 162$. In Ahmadou Sadio Diallo (Republic of Guinea v Democratic Republic of Congo), the ICJ established that this principle had certain exceptions depending on the facts and the claims presented. This case referred to inter alia the cruel, inhuman and degrading treatment afforded by the Democratic Republic of the Congo to a Guinean national. This claim was presented by Guinea. However, it could only be demonstrated by the information under the control of the Democratic Republic of the Congo. Hence, the ICJ established that the burden of proof lied on both sides. See Ahmadou Sadio Diallo (Republic of Guinea v Democratic Republic of Congo) [2010] (Merits) ICJ Rep 639 §§ 54-56. Conversely, in the particular context of futility of local remedies, the burden of proof lies on the claimant, since it is the former who alleges this futility.

156 Decreto Presidencial 214/02 of President Duhalde of the Argentine Republic.

157 The discussion remains in this point. There are certain experts that affirm that litigating in Argentinian domestic court was impossible, on the one hand. On the other hand, there are others that affirm that a decision by an Argentinian court in less than 18 months was feasible without a doubt. See BG Group v. Argentina (n. 8) §§ 155-157. 
Consequently, the most important legal consequence of the failure to meet the prerequisites is that tribunals lack jurisdiction to rule on the merits of the dispute, strictu sensu. On the other hand, this failure factually implies a double burden for the investor who seeks to file a dispute against a State. ${ }^{158}$

\section{Most Favored Nation Treatment (MFN) as an Alternative to the Compliance with the Prior Steps}

It is worthwhile mentioning that in recent years, investors, after rejecting the offer of arbitration or failing to meet the conditions for seisin, have bypassed this by appealing to the MFN clause of the relevant BIT and demanding the application of arbitration clauses existing in other BIT of the host State. The basic argument goes as follows: (i) allowing direct access to international arbitration, as provided in the BIT $X$ between the State $Y$ and the respondent State, represents a more favorable treatment than the one requiring compliance with prior steps to arbitration; (ii) the prima facie applicable BIT contains an MFN clause; (iii) the application of this clause should be extended to dispute settlement mechanisms and, therefore, the BIT $X$ is applicable and the terms of the arbitration offer or the conditions for seisin of the primary BIT are overruled. ${ }^{159}$ Maffezini v. Spain was the first case to accept that argument and establish its jurisdiction over the merits of the case, although it rendered the prior steps as mandatory. As a result of Maffezini, this issue has become one of the most controversial in ILFI. ${ }^{160}$

The purpose of this article is not to make a comprehensive analysis of this issue. Nonetheless, its understanding turns relevant. The doctrine of MFN has existed since the first international trade agreements. ${ }^{161}$ By virtue of this

158 First, to comply with the prior steps to arbitration, in accordance with its terms and the 1969 Vienna Convention (n.96) art. 26. Second, in case of failing to do the former, to prove that the remedies were futile, if it intends to proceed with the arbitration.

159 See Maffezini v. Spain (n.95) §§ 39-40.

160 Santiago Tawil, G., "Most Favored Nation Clauses and Jurisdictional Clauses in Investment Treaty Arbitration”, in Binder, C. et al. (eds.), International Investment Law for the 21 st Century: Essays in Honour of Christoph Schreuer (OUP, 2009), p. 10.

161 The principle can the traced back to the treaty between King Henry V of England with Duque Juan de Burugundy of Amiens, of 17 August 1417 in which it was allowed for the English ships to utilize maritime ports in the same way as the French, Scottish and Dutch ships amongst others. UNCTAD, Most Favoured-Nation Treatment, United Nations Conference on Trade and Development, UNCTAD Series on Issues in International Investment Agreements (1999), p 13. 
clause, a State agrees to afford another State or persons or things in a determined relationship with the latter, no less favorable treatment than the one extended to a third State, persons or things in the same relation to it, in similar circumstances. ${ }^{162}$ In its genesis, the MFN clause was not devised as a rule applicable to procedural issues in international dispute settlement. However, based on the principle of expresso unius est exclusio alterus, it has been determined that if MFN clauses do not explicitly exclude their application to procedural rules or jurisdictional clauses, then the former is applicable to the latter. ${ }^{163}$ Some cases regarding foreign investment has adopted this approach. ${ }^{164}$ Arguing for one or another position on this issue falls out of the scope of this article. However, it is important to remark that the decision on whether the MFN clause is applicable to dispute settlement mechanisms depends ultimately on the concept it is given to the jurisdictional consent of a State: if a restrictive view is adopted, then MFN clauses could hardly overrule the application of the precise terms of the compromissory clause of a BIT. ${ }^{165}$

\section{CONCLUSION}

The prior steps to arbitration, whether negotiations or domestic litigation, are obligations of the claimant investor who seeks recourse to international

162 Report of the Commission to the General Assembly on the Work of its Thirteenth Session, The Most-Favoured Nation Clause, Yearbook of the International Law Commission (1978), volume II, part 2, p. 18.

163 National Grid PLC v.Argentine Republic (Decision on Jurisdiction) (UNCITRAL) (20 June 2006) $§ 83$.

164 Gas Natural SDG, SA v. The Argentine Republic (Decision of the Tribunal on Preliminary Questions on Jurisdiction) (ICSID Case No. ARB/03/10) (17 June 2005) § 31; Telefónica SA v. Argentine Republic (Decision of the Tribunal on Objections to Jurisdiction) (ICSID Case No. ARB/03/20) (25 May 2006) § 103; Suez, Sociedad General de Aguas de Barcelona, SA and Vivendi Universal, SA v. Argentine Republic (Decision on Jurisdiction) (ICSID Case No. ARB/03/19) (3 August 2006); AWG Group Ltd. v. The Argentine Republic (Decision on Jurisdiction) (UNCITRAL) (3 August 2006). For arguments contrary to what the previous cases ruled, see for instance Teinver SA and others $v$ Argentina (Decision on jurisdiction, Separate Opinion of Dr. Kamal Hossain) (ICSID Case No ARB/09/1) (21 December 2012) §§ 7-18.

165 Gaillard, E., "Establishing jurisdiction through a Most-Favored-Nation Clause", 2005, 233 The New York Law Journal, 105. 
arbitration against a host State. Only through the fulfillment of these prior steps may the investor lawfully submit its claims before an international tribunal. Therefore, the prior steps can be considered as elements of the arbitration offer of the host State or as elements of seisin of the tribunal. In the first case, the failure to comply with these prior steps amounts to a lack of an arbitral agreement and ergo of the jurisdiction ratione voluntatis of the tribunal, whilst in the second case there is jurisdictional consent of the parties, but with no legal effect. Although both approaches are technically distinguishable, their legal outcome is the same: the tribunal may not adjudicate on the merits of the case whenever the prior steps to arbitration are not fulfilled.

Achieving these approaches depended on a particular legal exercise consisting of (i) the juridical distinction between jurisdiction, admissibility and seisin, and its main features; (ii) the conceptual distinction of the prior steps to arbitration with other similar juridical institutions (such as the exhaustion of local remedies and bona fide negotiations), and (iii) the application of the general rules of interpretation of treaties.

Arbitrators have had divergent views on either of the previous steps, which have led them to disparate results. However, this does not mean that the prior steps to arbitration, as a juridical concept of ILFI, lack a homogeneous legal meaning per se. Therefore, the legitimacy crisis in ILFI outlined in the introduction is due in part to the fact that arbitrators tend to follow different analytical paths to interpret the same subject matter. ${ }^{166}$ However, the different legal paths and analysis that arbitrators may take whilst dealing with same juridical questions is also one of the main assets of international arbitration: it gives a different perspective of a legal issues and allows parties to a dispute to appoint an arbitrator based on their previous decisions and their general background expecting a specific legal analysis to be made by him or her.

166 For a detailed explanation on different applications of the general rules of treaty interpretation, see Saldarriaga, A., "Investment Awards and the Rules of Interpretation of the Vienna Convention: Making Room for Improvement”, 1 ICSID Review 28, 2013, p. 201. 


\section{BIBLIOGRAPHY}

ABI-SAAB. G., Les exceptions préliminaires dans la procédure de la Cour internationale de Justice, París, A. Pedone, 1967.

AlvareZ, J. E. \& Khamsi, K., "The Argentinian Crisis and Foreign Investors", in Sauvant, K. P. (ed.), International Investment Law and Policy 2008 /2009, OUP, 2009.

Amerasinghe, C. F., Evidence in International Litigation, Martinus Nijhoff Publishers, 2005.

The Hague, 2003.

Jurisdiction of International Tribunals, Kluwer Law International, , Jurisdiction of Specific International Tribunals, Martinus Nijhoff, Leiden-Boston, 2009.

—, Local Remedies in International Law, CUP, 2005.

- Submission to the Jurisdiction of the International Centre for Settlement of Investment Disputes (1973-1974) 5 JMarL\&Com 211.

Bernasconi-Osterwalder, N. \& Johnson, L., Commentary to the Austrian Model Investment Treaty, Study commissioned by the Chamber of Labour for Vienna, Austria Vienna, November 2011.

Blum, Y. Z., "Note and Comment: Consistently Inconsistent: The International Court of Justice and the Former Yugoslavia (Croatia v. Serbia)", 103 AJIL 264, 2009.

BodDICKER, J., Whose Dictionary Controls?: Recent Challenges to the Term "Investment" in ICSID Arbitration, 25 AUILR 5, 2010.

Boisson de ChazouRnes, L., "The principle of Compétence de la Compétence in International Adjudication and its Role in an Era of Multiplication of Courts and Tribunals", in ARSANJI, M. H. et al. (eds.) Looking to the Future: Essays on International Law in Honor of W. Michael Reisman Leiden, Martinus Nijhoff, 2011.

Brower, C. N. et al., "The Coming Crisis in the Global Adjudication", 19 Arbitration International 415, 2003.

Brown, C., A Common Law of International Adjudication, OUP, 2007.

CRAWFORD. J., Brownlie's Principles of International Law, 8th ed., OUP, 2012.

DIJK, V. et al., Theory and Practice of the European Convention on Human Rights, Oxford, Hart Publishing, 2006.

Dimsey, M., The Resolution of International Investment Disputes: International Commerce and Arbitration 98, Ingeborg Schwenzer ed., 2008. 
Dodges, W., National Courts and International Arbitration: Exhaustion of Remedies and Res Judicata under Chapter 11 of NAFTA, 23 HI\&CL 357.

DOLZER, R., "The Notion of Investment in Recent Practice", in CHARMOVITZ et al. (eds.), Law in the Service of Human Dignity: Essays in Honour of Florentino Feliciano, CUP, 2005.

\section{2.}

\& SChreuerm C., Principles of International Investment Law, OUP,

Douglas, Z., The International Law of Investment Claims, CUP, 2009.

DUGAN, C. F., Investor-State Arbitration, OUP, 2008. et al., Investor-State Arbitration, OUP, 2008.

EBERE, S. \& Xheraj, B., "Who Decides Arbitrability Where a Precondition to Arbitration Has Not Been Satisfied?: A Comment on the U.S. Supreme Court's Decision to Hear the Appeal in BG Group v. Argentina”, 31 Journal of International Arbitration 1, 2014.

FitzMaurice. G., The Law and Procedure of the International Court of Justice, British Yearbook of International Law, 1986.

FRY, J. D. \& Repousis, O., "Stripping the jurisdiction from established investment arbitral tribunals" (2013) International Law Association Regional Conference 2013 | 29-31 August 2013, Cape Sounion, Greece (Resume available at http: / / www.ilaregional2013.gr/images / pdf/abstract / 30August / 21.\%20James\%20Fry\%20abstract.pdf. Last visited 15 May 2014).

GAILlaRD, E., Establishing jurisdiction through a Most-Favored-Nation Clause (2005) 233 The New York Law Journal 105.

Gourgourinis, A., “'Investors' Rights qua Human Rights? Revisiting the 'Direct' / 'Derivative' Rights Debate” in Fitzmaurice, M. \& Merkouris, P., The Interpretation and Application of the European Convention of Human Rights Legal and Practical Implications, Martinus Nijhoff, 2012.

GRAY, C., Judicial Remedies in International Law, OUP, 1987.

Heiskanen, V., "Ménage à trios", Jurisdiction, admissibility and competence in investment treaty arbitration, ICSID Review, 2013.

Herdegen, M., "Interpretation in International Law", The Max Planck Institute of International Law, Rüdiger Wolfrum, 2008.

JOUANNET, E., "Le saisine dans le droit international ou la simplicité dans la diversité”, in RuIz FABRI, H. \& SOREL, J. M. (ed.), La saisine des juridictions internationales, París, Pedone, 2006. 
Kolb, R., "General Principles of Procedural Law", in Zimmermann, A. et al. (eds.), The Statute of the International Court of Justice. A Commentary, Oxford University Press, 2006.

Lalive, P., "The First World Bank Arbitration (Holiday Inns v Morocco) Some Legal Problems", 51 BritishYearbook of International Law, 1980.

Lauterpacht, H., "Restrictive Interpretation and the Principle of Effectiveness in the Interpretation of Treaties", 26 British Yearbook of International Law 48, 1949.

LOSSARI, J. \& Ewing-Chong, M., Legitimate Countermeasures in International Trade Law and their Illegality in International Investment Law (2013) International Law Association Regional Conference 2013 | 29-31 August 2013, Cape Sounion, Greece (Draft available at http://cil.nus.edu.sg/wp/wpcontent/uploads / 2013/09/JamesLosari-MEwing-Chow-Countermeasures-inInternational-Trade-Law-Paper.pdf. Last visited 14 May 2014).

Paulsson, J., Denial of Justice in International Law (CUP, 2005).

, 'Jurisdiction and admissibility' in G Aksen \& R Briner (eds), Global Reflections on International Law, Commerce and Dispute Resolution, Liber Amicorum in honour of Robert Briner (ICC Publishing, 2005).

Pellet, A., Lalive Lecture, "The Case Law of the ICJ in Investment Arbitration”, 22 ICSID Review 2. 2013 , "The Anatomy of Courts and Tribunals", 3 The Law \& Practice of International Courts and Tribunals, 2008. Peterson, L. E., Argentina by the Numbers: Where Things Stand with Investment treaty Claims Arising out of the Argentine Financial Crisis (1 February 2011) (Available at http: / / www.iareporter.com/articles/20110201_9. Last visited 10 June 2014).

RANK, W. et al., ICSID Emerging Jurisprudene: The Scope of ICSID's Jurisdiction, (1986-1987) 19 NYJIntL\&Pol 33.

Report of the Commission to the General Assembly on the Work of its Thirteenth Session, The Most-Favoured Nation Clause, Yearbook of the International Law Commission (1978), volume II, part 2.

Rivkin, D. W., "Towards a New Paradigm in International Arbitration: The Elder Town Model Revisited”, 24 Arbitration International 375, 2008.

Rosenne, S., The Law and Practice of the International Court of Justice, 4th edn., vol. II, Martinus Nijhoff 2006.

Rudolf Braun, T., Globalization-Driven Innovation: The Investor as a Partial Subject in Public International Law - An Inquiry Into the Nature and Limits of 
Investor Rights, Jean Monet Working Paper 04/13 NYU School of Law, 2013.

SALDARRIAGA A., Investment Awards and the Rules of Interpretation of the Vienna Convention: Making Room for Improvement (2013) 1 ICSID Review 28.

SAlaCUSE, J., The Law of Investment Treaties, OUP, 2010.

SAntiago TAWIL, G., "Most Favored Nation Clauses and Jurisdictional Clauses in Investment Treaty Arbitration", in BINDER, C. et al. (eds.), International Investment Law for the 21 st Century: Essays in Honour of Christoph Schreuer, OUP, 2009.

SCHWEBEL, S. \& WeTter, G., "Arbitration and Exhaustion of Local Remedies", 60 AJIL 484, 1966.

-, "Arbitration and the Exhaustion of Local Remedies Revisited", in Festschrift for Joseph Gould, 1989.

SCHREUER, C., At what time must jurisdiction exist? (For thcoming) (Available at http: / / www. univie.ac.at/intlaw / wordpress / wp-content / uploads / 2014/01 / At-what-Time-Jurisdiction.pdf. Last visited 6 June 2014).

, “Calvo's Grandchildren: The Return of Local Remedies in Investment Arbitration", 4 The Law and Practice of International Courts and Tribunals, 2004.

, Diversity and Harmonization of Treaty Interpretation in Investment Arbitration, 2006, 3 TDM 2.

, The ICSID Convention, A Commentary (A Commentary on the Convention on the Settlement of Investment Disputes between States and National of Other States), CUP, 2001.

- "Travelling the BIT route: OfWaiting Periods, Umbrella Clauses and Forks in the Road”, 5 JWIT 2, 2004.

SINCLAIR, A. et al., ICSID Arbitration: How long does it take?, 2009, 4 GARJ 5.

SORnARAJAH, M., The International Law on Foreign Investment, Cambridge, CUP, 2004.

Szasz, P., The Investment Disputes Convention: Opportunities and Pitfalls (how to submit to ICSID), (1970-1971) 5 JLED 23.

ThIRlWAY, H., "The Law and Procedure of the International Court of Justice 1960-1989 (Parts Nine and Ten)" (2001), 1 British Yearbook of International Law, 2011.

Tupman, W. M., Case Studies in the Jurisdiction of the International Centre for Settlement of Investment Disputes, 1986, 35 ICLQ 813. 
UNCTAD, Most Favoured-Nation Treatment, United Nations Conference on Trade and Development, UNCTAD Series on Issues in International Investment Agreements, 1999.

VISSCHER, C. de, Theory and reality in public international law, New Jersey, Princeton, 1968.

Waibel, M. et al., "The Backlash Against Investment Arbitration: Perceptions and Reality", in Waibel, M. (eds.) The Backlash Against Investment Arbitration: Perceptions and Reality, Kluwer Law International, The Netherlands.

WeIL, P., 'Compétence et saisine: un nouvel aspect du principe de la juridiction consensuelle' en Makarczyk, J. (ed.), Theory of International Law at the Threshold of the Twenty First Century, The Netherlands, Brill Academic Publishers, 1996.

WyLER. E., "La détermination par la Cour de sa propre compétence", in Apostolidis, C. (ed.), Les arrêts de la Cour internationale de Justice, Dijon, Etudes universitaires de Dijon, 2005.

ZeIler, G., "Jurisdiction, Compétence and Admissibility of Claims in ICSID arbitration proceedings", in BINDER, C. et al. (eds.), International Investment Law for the $21^{\text {st }}$ Century, Essays in Honour of Christoph Schreuer, OUP, 2009. 